UNIVERSIDADE ESTADUAL PAULISTA "JÚLIO DE MESQUITA FILHO" FACULDADE DE CIÊNCIAS AGRONÔMICAS

CAMPUS DE BOTUCATU

\title{
EXPRESSÃO SEXUAL EM LINHAGENS DE MAMONA (Ricinus
}

communis $\mathbf{L}$.)

\author{
ANA CAROLINA DA COSTA LARA
}

Dissertação apresentada à Faculdade de Ciências Agronômicas da Unesp - Campus de Botucatu, para obtenção do título de Mestre em Agronomia (Agricultura).

BOTUCATU - SP

Fevereiro - 2010 
UNIVERSIDADE ESTADUAL PAULISTA "JÚLIO DE MESQUITA FILHO" FACULDADE DE CIÊNCIAS AGRONÔMICAS

CAMPUS DE BOTUCATU

\title{
EXPRESSÃO SEXUAL EM LINHAGENS DE MAMONA (Ricinus \\ communis $\mathbf{L}$.
}

\author{
ANA CAROLINA DA COSTA LARA \\ Orientador: Prof. Dr. Maurício Dutra Zanotto
}

Dissertação apresentada à Faculdade de Ciências Agronômicas da Unesp - Campus de Botucatu, para obtenção do título de Mestre em Agronomia (Agricultura)

BOTUCATU - SP

Fevereiro - 2010 
FICHA CATALOGRÁFICA ELABORADA PELA SEÇÃO TÉCNICA DE AQUISIÇÃO E TRATAMENTO DA INFORMAÇÃO - SERVIÇO TÉCNICO DE BIBLIOTECA E DOCUMENTAÇẪO - UNESP - FCA - LAGEADO - BOTUCATU (SP)

Lara, Ana Carolina da Costa, 1984-

L318e Expressão sexual em linhagens de mamona (Ricinus communis L.) / Ana Carolina da Costa Lara. - Botucatu : [s.n.], 2010 . ix, 62 f. : gráfs., tabs.

Dissertação (mestrado) - Universidade Estadual Paulista, Faculdade de Ciências Agronômicas, Botucatu, 2010 Orientador: Maurício Dutra Zanotto Inclui bibliografia.

1. Mamona. 2. Expressão sexual. 3. Linhagens. 4. Mamona - Produtividade. 5. Mamona - Plantas femininas. I. Zanotto, Maurício Dutra. II. Universidade Estadual Paulista "Júlio de Mesquita Filho" (Campus de Botucatu). Faculdade de Ciências Agronômicas. III. Título. 


\section{UNIVERSIDADE ESTADUAL PAULISTA "JÚLIO DE MESQUTTA FILHO" FACULDADE DE CIÊNCIAS AGRONÔMICAS \\ CAMPUS DE BOTUCATU \\ CERTIFICADO DE APROVAÇÃO}
TÍTULO: "EXPRESSÃO SEXUAL EM LINHAGENS DE MAMONA Ricinus communis L.)"

ALUNA: ANA CAROLINA DA COSTA LARA

ORIENTADOR: PROF. DR. MAURÍCIO DUTRA ZANOTTO

Aprovado pela Comissão Examinadora
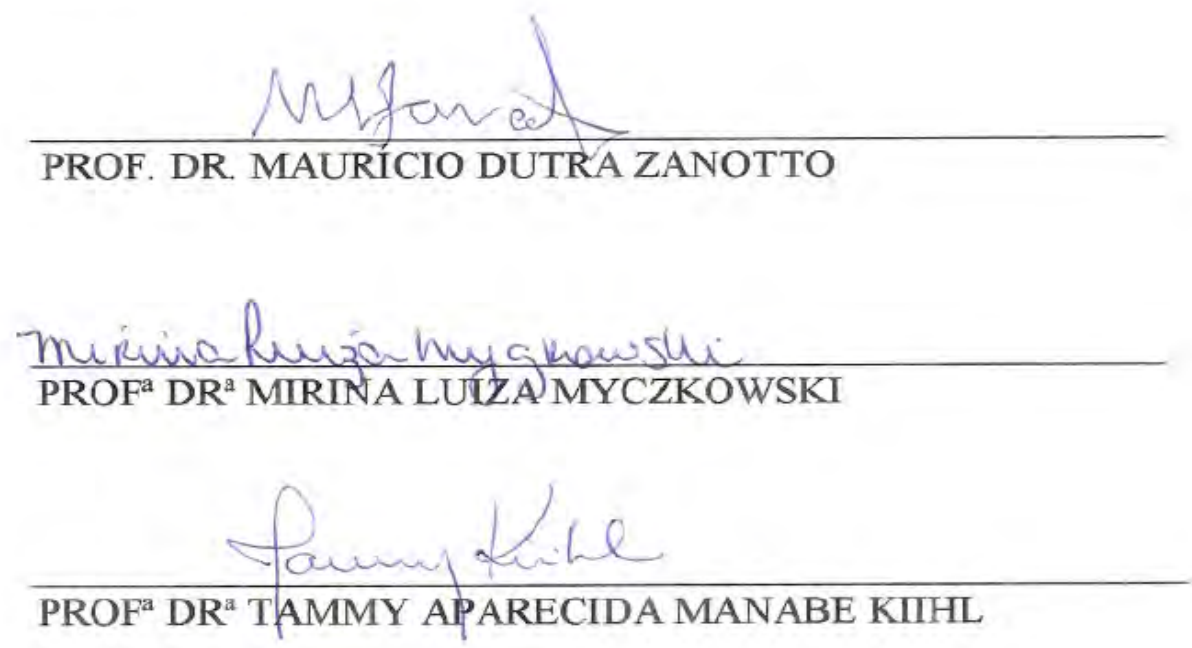

Data da Realização: 08 de fevereiro de 2010. 
À minha querida mãe, Fernanda Maria da Costa, por todo o amor e ajuda em todos os momentos da minha vida.

Aos meus amados avós, João Baptista da Costa (in memorian) e Terezinha Carrara da Costa (in memorian), que mesmo em distância física, tenho certeza que olham por mim. Por toda a lição de vida que me ensinaram.

\section{DEDICO.}

À Deus, por guiar meus caminhos e iluminar minha vida. Pelo amor e força que nunca me deixaste faltar.

\section{OFEREÇO.}




\section{AGRADECIMENTOS}

Á Deus, pela presença constante em minha vida, iluminando e guiando meus caminhos: força indispensável.

Ao meu orientador e amigo, Prof. Dr. Maurício Dutra Zanotto, por toda a atenção, dedicação e ensinamentos. Pela orientação acadêmica e de vida que me destes. Seu caráter profissional será sempre um exemplo para minha vida.

Á Faculdade de Ciências Agronômicas - UNESP/Botucatu, por me acolher como aluna no curso de Mestrado.

À CAPES - Coordenação de Aperfeiçoamento de Pessoal de Nível Superior - pela concessão da bolsa de estudos.

À todos os professores do Departamento de Produção Vegetal - Agricultura, da Faculdade de Ciências Agronômicas - UNESP/ Botucatu pela atenção e ensinamentos, em especial ao professor Dr. Rogério Peres Soratto, pelo incentivo e amizade.

Aos queridos funcionários do Departamento de Produção Vegetal - Agricultura, da Faculdade de Ciência Agronômicas - UNESP/ Botucatu, em especial a Vera, Lana e o Dorival, pela ajuda, paciência e amizade.

Aos técnicos Augusto e Daniel pela ajuda nos experimentos na Fazenda de São Manuel e em especial ao técnico Milton (Seu Milton) por auxiliar em todas as etapas do meu trabalho, com muita paciência e disposição.

Ao técnico temporário Jota, querido amigo, pela ajuda nas avaliações dos meus experimentos e pelos ensinamentos. 
Aos meus queridos estagiários Cristiane Harumi Okita, Henrique Trevisanuto e Bruna Lorenço Santos, pela ajuda e dedicação ao meu trabalho, desejo-lhes que continuem nesse caminho.

Aos motoristas da Faculdade de Ciências Agronômicas - UNESP/ Botucatu, que durante a execução dos experimentos me levaram semanalmente à São Manuel-SP, e pelos colegas conquistados na viagem.

À todos os amigos do Departamento de Produção Vegetal - Agricultura, da Faculdade de Ciência Agronômicas - UNESP/ Botucatu, em especial aos amigos da área de melhoramento de plantas: Laerte Gustavo Pivetta, Fernanda Bertozzo, Ilka e Haroldo, pela ajuda nos trabalhos, pelos conhecimentos divididos e pela amizade acima de tudo.

À todos os amigos que, direta ou indiretamente, me ajudaram a concluir o mestrado e fazer desta fase a mais especial da minha vida: Lívia (Sardinha), Camila (Tostines), Lívia Losi, Paty, Cris, Carla, Mariana, Gustavo (Spirro), Samuel, Gustavo, Laércio, Priscila (Pira), Genivaldo, Saulo, Magno, Rômulo (Khaled), Renata (Tintinha)....Obrigada pela convivência maravilhosa.

À minha família, que mesmo em distância física, rezou por mim e sempre me apoiou na realização do meu trabalho, em especial a minha mãe querida, Fernanda Maria da Costa, pelo amor incondicional.

À todos que contribuíram para a realização deste trabalho, meus sinceros agradecimentos! 


\section{SUMÁRIO}

Página

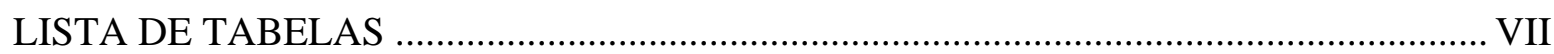

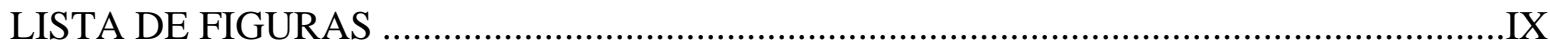

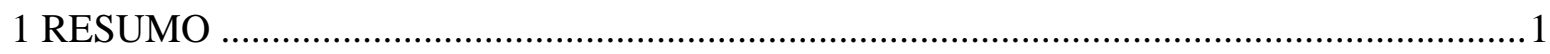

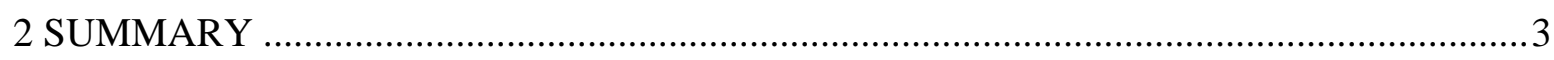

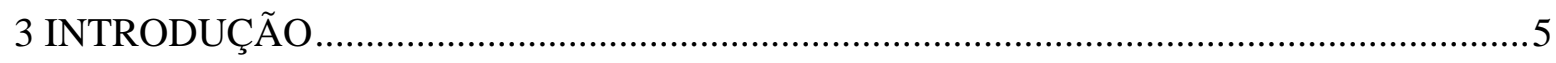

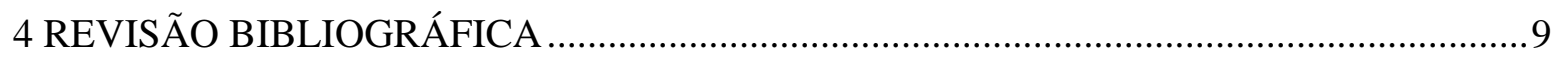

4.1 Origem e distribuição geográfica da cultura da mamona .................................................

4.2 Aspectos botânicos, morfológicos e fisiológicos da mamona .......................................... 10

4.3 Aspectos socioeconômicos da cultura da mamona........................................................... 13

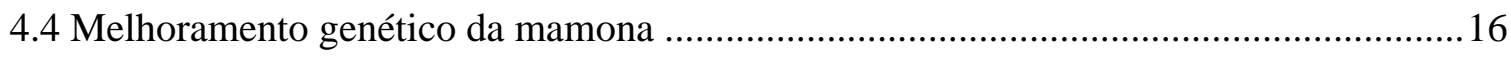

4.5 Florescimento e expressão do sexo em mamona........................................................19

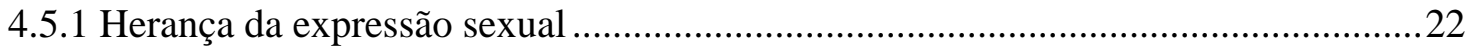

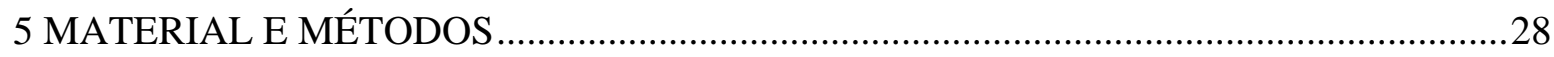

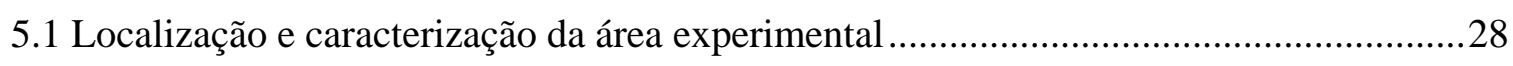

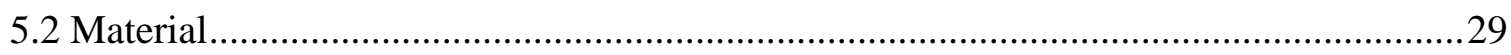

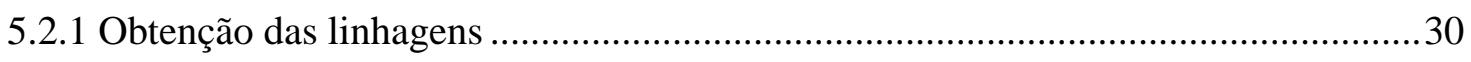

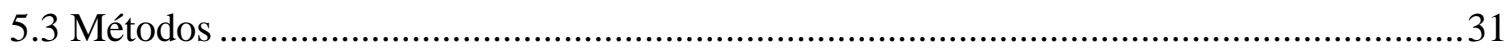

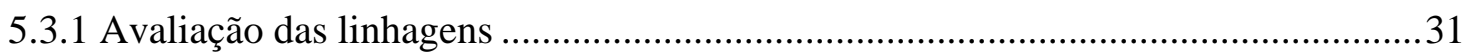

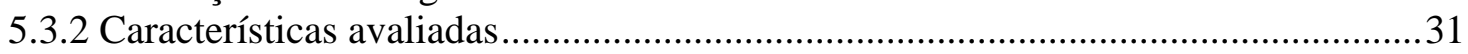

5.3.3 Delineamento experimental e análises estatísticas .............................................. 32

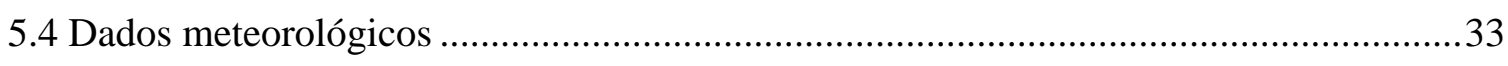

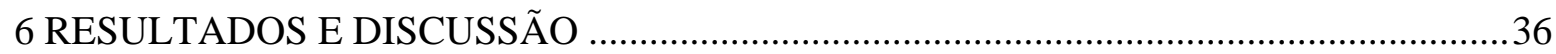

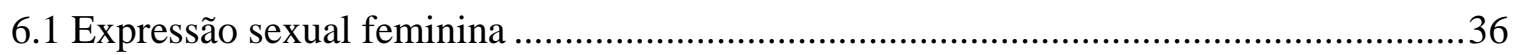

6.2 Altura de planta, altura de inserção do racemo primário, diâmetro de caule e número de

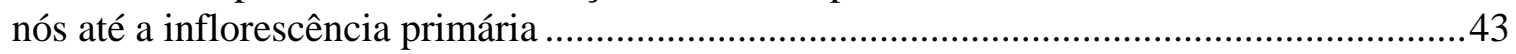

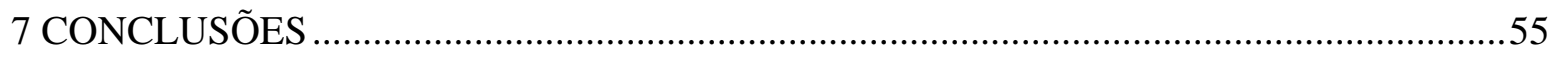

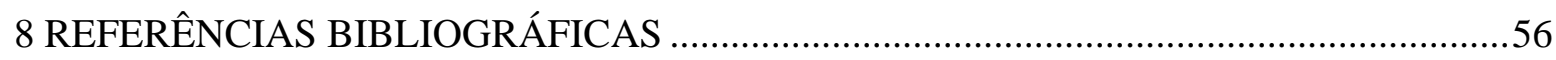




\section{LISTA DE TABELAS}

Página

Tabela 1. Relação das linhagens de mamona avaliadas nos experimentos de Botucatu-SP e São Manuel-SP, na safrinha de 2008.

Tabela 2. Frequiências de plantas femininas nas 80 linhagens de mamona, avaliadas nos municípios de Botucatu- SP e São Manuel-SP, na safrinha de 2008.

Tabela 3. Total de plantas femininas (PF), plantas femininas estáveis (PFE) e plantas femininas com flores estaminadas intercaladas (PFEI) observadas nas 80 linhagens de mamona, nos municípios de Botucatu-SP e São Manuel-SP, safrinha de 2008.

Tabela 4. Quadrados médios obtidos das análises de variâncias para as características altura de planta (AP), altura de inserção do racemo primário (AI), diâmetro de caule (DC) e número de nós da haste principal até a primeira inflorescência $(\mathrm{NN})$, avaliados em linhagens de mamona, no município de Botucatu-SP, safrinha de 2008.

Tabela 5. Quadrados médios obtidos das análises de variâncias para as características altura de planta (AP), altura de inserção do racemo primário (AI), diâmetro de caule (DC) e número de nós da haste principal até a primeira inflorescência $(\mathrm{NN})$, avaliados em linhagens de mamona, no município de São Manuel-SP, safrinha de 2008. .44

Tabela 6. Médias gerais para as características altura de plantas (AP), altura de inserção do racemo primário (AI), diâmetro de caule (DC) e número de nós da haste principal até a primeira inflorescência (NN), avaliadas em linhagens de mamona, experimento em BotucatuSP, safrinha de 2008 . .44

Tabela 7. Médias gerais para as características altura de plantas (AP), altura de inserção do racemo primário (AI), diâmetro de caule (DC) e número de nós da haste principal até a primeira inflorescência $(\mathrm{NN})$, avaliadas em linhagens de mamona, no município de São Manuel-SP, safrinha de 2008.

Tabela 8. Quadrados médios, respectivas significâncias pelo teste F e coeficientes de variação experimental da análise conjunta, das linhagens de mamona para as características altura de 
plantas $(\mathrm{cm})$, altura de inserção do racemo primário $(\mathrm{cm})$, diâmetro de caule e número de nós na haste até a inflorescência, em Botucatu - SP e São Manuel - SP, na safrinha 2008. .50

Tabela 9. Médias das linhagens de mamona para as características altura de plantas (AP) e altura de inserção do racemo primário (AI) nos municípios de Botucatu - SP e São Manuel, na safrinha de 2008. 


\section{LISTA DE FIGURAS}

Página

Figura 1. Temperaturas máxima, mínima e média no município de Botucatu, no período de 01 de abril a 29 de dezembro de 2008, referente ao cultivo da safrinha, 2008.

Figura 2. Precipitação em mm no município de Botucatu, no período de 01 de abril a 29 de dezembro de 2008, referente à safrinha de 2008. Freqüência acumulada 679,5 mm.

Figura 3. Temperaturas máxima, mínima e média no município de São Manuel, no período de 01 de março a 26 de dezembro de 2008 , referente ao cultivo da safrinha.

Figura 4. Precipitação em mm no município de São Manuel, no período de 01 de abril a 29 de dezembro de 2008, referente à safrinha de 2008. Freqüência acumulada 724,5 mm. .35

Figura 5. Freqüência de plantas monóicas obtidas nas 80 linhagens de mamona, no município de Botucatu-SP, safrinha 2008.

Figura 6. Freqüência de plantas monóicas obtidas nas 80 linhagens de mamona, no município de São Manuel-SP, safrinha 2008. 


\section{RESUMO}

A inflorescência padrão da mamoneira é um racemo com flores femininas no ápice e masculinas na base, porém há muitas variantes para esse tipo de expressão sexual, determinada por fatores genéticos e ambientais. A produtividade da mamoneira está diretamente relacionada com a proporção de flores femininas no racemo. $\mathrm{O}$ objetivo do presente trabalho foi avaliar 80 linhagens de mamona quanto à característica de expressão sexual. As linhagens são oriundas do programa de melhoramento de mamona da Faculdade de Ciências Agronômicas da UNESP campus de Botucatu. Os experimentos foram instalados na Fazenda Experimental São Manuel, no município de São Manuel- SP e na Fazenda Experimental Lageado, município de Botucatu- SP, ambos pertencentes à Faculdade de Ciências Agronômicas- UNESP campus de Botucatu, em condições de safrinha, no período de abril a dezembro de 2008.

As 80 linhagens utilizadas foram selecionadas para alta porcentagem de florescimento feminino, com ciclos de seleção e autofecundação.

O delineamento experimental utilizado foi de blocos ao acaso com duas repetições. As parcelas experimentais foram constituídas de uma linha de 2,0 m com 5 plantas e o espaçamento utilizado foi de 0,5 m entre plantas, $1 \mathrm{~m}$ entre linhas e área útil de 2,0 $\mathrm{m}^{2}$.

Foram avaliadas as frequiências de plantas femininas e plantas monóicas em cada linhagem, assim como a estabilidade da feminilidade em todos os racemos 
e em ambos os ambientes. Foram avaliadas também a altura de planta, altura de inserção do racemo primário, diâmetro do caule e número de nós da haste até a inflorescência primária.

Os dados obtidos foram submetidos às análises de variância individual e conjunta, pelo teste $\mathrm{F}$ a $5 \%$ de probabilidade, para os dois municípios, e as médias comparadas pelo teste de Scott-Knott a 5\% de probabilidade, com o uso do programa SISVAR v.4.2.

Pela análise individual foram observadas significâncias para todas as características, em ambos os municípios. Foi verificada uma grande variabilidade entre as linhagens, e todas apresentaram porte adequado para produção de híbridos para a colheita mecanizada. Na análise conjunta, houve significância para o quadrado médio da interação Linhagem X Local, para as características diâmetro de caule e número de nós da haste até a inflorescência primária, demonstrando que as linhagens apresentaram comportamento diferencial para tais características, não podendo serem comparadas em termos médios.

Com relação à expressão sexual, verificou-se que nas condições ambientais do município de Botucatu-SP as linhagens apresentaram 65,7 \% de plantas femininas estáveis, enquanto que nas condições ambientais do município de São Manuel-SP as linhagens apresentaram 58,1\%. As condições ambientais do município de Botucatu mostraram-se mais favoráveis à expressão sexual feminina, contudo em ambos os municípios as linhagens apresentaram grande potencial, algumas delas com alta freqüência de plantas femininas, observando que para tais linhagens, os ciclos de seleção e autofecundação foram eficientes para a característica pistilada.

Palavras-chave: Inflorescência padrão, produtividade, seleção, plantas femininas, variabilidade. 
SEXUAL EXPRESSION IN CASTOR BEAN (Ricinus communis L.) LINES Botucatu, 2010. 60p. Dissertação (Mestrado em Agronomia/Agricultura) - Faculdade de Ciências Agronômicas, Universidade Estadual Paulista.

Author: ANA CAROLINA DA COSTA LARA

Adviser: MAURÍCIO DUTRA ZANOTTO

\section{SUMMARY}

The standard of castor bean inflorescence is a raceme, with female flowers located at the apex of the plant, and male flowers at the base. However this type of sexual expression can vary according to genetic and environmental factors. The castor bean yield is related to the proportion of female flowers in the raceme. Therefore, the purpose of this study was to evaluate eighty lines of castor bean regarding to the sexual expression characteristic. These lines were derived from the program of castor bean breeding from the Faculdade de Ciencias Agronomicas - Universidade Estadual Paulista "Julio de Mesquita Filho", Botucatu Campus. The experiments were conducted as second crop, in period april to december in 2008 at the Experimental Farm Sao Manuel, in Sao Manuel - SP, and at the Experimental Farm Lageado, in Botucatu - SP, both from the Faculdade de Ciencias Agronomicas - UNESP, Botucatu Campus.

The 80 lines used were selected for high percentage of female flowers, with selection and selfing cycles.

The experimental design consisted by randomized blocks with two replications. The plots consisted by one row of $2.0 \mathrm{~m}$ with five plants and the spacing used was $0.5 \mathrm{~m}$ between plants, $1 \mathrm{~m}$ between lines, being $2.0 \mathrm{~m}^{2}$ of total area.

The female plants and monoecious plants frequencies in each line were evaluated, as well as the femininity stability in all racemes for both experiments. Plant height, height of primary raceme insertion, stem diameter, and number of nodes from the stem to the primary inflorescence were evaluated as well. 
The data were submitted to individual and joint variance analysis, by test $\mathrm{F}$ at $5 \%$ probability, for both experiments, and the averages compared by Scott-Knott test with $5 \%$ of probability through SISVAR Program, 4.2 version.

By individual analysis, significant differences were observed in all characteristics for both experiments. A great variability among the lines was observed, and all lines showed appropriate size for production of hybrids to mechanized harvest. The joint analysis indicated statistic significance to the mean square for stem diameter and number of nodes from the stem to the primary inflorescence, showing that the lines presented different behavior for the characteristics cited above, and could not be compared on averages.

Regarding to sexual expression, was verified that in climatic conditions of Botucatu - SP, the lines presented 65,7\% of stable female plants, while in climatic conditions of Sao Manuel - SP, the lines presented 58,1\%. The climatic conditions of Botucatu showed to be more favorable to female sexual expression. Nevertheless, in both cities the lines showed a great potential, some of them indicated high frequency of female plants, observing that the selection and selfing cycles were effective for pistillate characteristics.

Key words: Standart inflorescence, yield, selection, female plants, variability. 


\section{INTRODUÇÃO}

A mamoneira (Ricinus communis L.) é uma oleaginosa da família Euphorbiaceae, que foi plenamente adaptada às condições edafoclimáticas brasileiras, sendo encontrada praticamente em todo o território nacional. O grande potencial da mamoneira está em suas sementes com alta capacidade de produção de óleo.

O óleo de mamona é um dos mais versáteis da natureza com a vantagem de ser renovável e sua singularidade dá-se em virtude de sua composição quase que exclusiva do ácido graxo ricinoléico, que faz com que o óleo apresente alta viscosidade e estabilidade em larga faixa de condições de temperatura. É matéria-prima para mais de quatrocentos produtos, sendo usado nas indústrias farmacêutica, cosmética e alimentícia (AZEVEDO et al., 1998; AMARAL, 2003).

Durante décadas o Brasil ocupou o posto de maior produtor de mamona em baga e maior exportador de óleo de mamona do mundo, responsável por cerca de 30 a $45 \%$ da produção mundial até a década de 70. No entanto, o Brasil perdeu a hegemonia para países como a Índia e China, principalmente em função do alto custo da colheita manual (SAVY FILHO et al., 1997).

A cultura da mamona ganhou impulso na economia com o uso de seu óleo para a produção de biodiesel. O Programa Nacional de Biodiesel impulsionou a produção de mamona, além de promover a expansão da área de cultivo. A cultura da mamona tinha sua importância somente no Nordeste, e se tratava basicamente de agricultura familiar. Contudo, o 
valor agregado de seu óleo fez com que produtores se interessassem pela cultura, e o cultivo da mamoneira se expandiu em diversas regiões do país.

O rendimento médio da mamona em bagas, no Brasil, na safra de 2008 foi de $770 \mathrm{~kg} \cdot \mathrm{ha}^{-1}$ (IBGE, 2009), considerado baixo já que a mamoneira produz rendimentos maiores. O principal fator que influencia a produtividade baixa da cultura da mamona no Brasil é o baixo nível tecnológico empregado pelos produtores e a pouca oferta de genótipos (cultivares e híbridos) que apresentem resistência a doenças e adaptação aos diferentes ambientes de cultivo.

Segundo SAVY FILHO (1999a), ao longo dos anos de pesquisa e experimentação com a cultura da mamoneira, estabeleceram-se parâmetros de uma cultivar modelo, ou um ideótipo de planta, para balizar o desenvolvimento de novas cultivares. As características agronômicas consideradas ideais, básicas, na composição de uma nova cultivar, passível de maximizar o rendimento econômico e industrial da cultura da mamoneira, são as seguintes: porte baixo, para facilitar a colheita, possibilitando maior número de plantas por área; alto potencial de produtividade de grãos; resistência às principais doenças (causadas por Fusarium, Botrytis, Alternaria e Xanthomonas); frutos indeiscentes no campo, minimizando as perdas antes e durante a colheita; sementes de tamanho médio, uniformes e com alto teor de óleo.

A mamoneira é uma planta que apresenta como inflorescência padrão racemos monóicos, com flores femininas no ápice e masculinas na base do racemo, em proporções que variam. Essa variação apresenta influência genética e ambiental. Além de plantas monóicas, são encontradas na natureza plantas de mamona que apresentam o racemo inteiramente coberto com flores femininas. As plantas femininas de mamona são de grande interesse, porque podem ser mais produtivas em comparação com as monóicas, e para a utilização dessas linhas femininas para a produção de híbridos de mamona.

A hibridação é de grande interesse no melhoramento da maior parte das espécies cultivadas, tanto para a exploração do vigor de híbrido na geração F1 como também para promover o aparecimento de variabilidade genética em populações. O vigor híbrido, ou heterose é a capacidade de o F1, obtido da hibridação de dois germoplasmas com boas características, superá-las, com vantagem em relação à média dos pais (MIRANDA FILHO \& NASS, 2001). 
Os programas de melhoramento da mamona no Brasil possuem como objetivo principal o desenvolvimento de cultivares, não sendo a produção de híbridos um dos objetivos. Esse fato ocorre porque a mamoneira é cultivada, principalmente, por produtores na região Nordeste, com baixa tecnologia, sendo tradicionalmente uma cultura de pequenos produtores. O pequeno e médio produtor tem características e nível peculiares que devem ser considerados, como por exemplo, exigência de cultivar que permita a condução da cultura manualmente, do plantio à colheita. Já o produtor de maior porte, especialmente de regiões em que a mamoneira não é cultura tradicional, nas quais, por motivos agronômicos e econômicos, a cultura pode entrar na composição da receita da empresa agrícola, os conceitos para o desenvolvimento de cultivares mudam radicalmente. Nessas regiões, onde há dominância da prática de agricultura tecnificada, os híbridos se encaixam perfeitamente devido a sua melhor uniformidade, ciclo precoce, resposta aos insumos agrícolas e permitindo a colheita mecanizada (SAVY FILHO, 1999b).

Para a síntese de híbridos normalmente são eleitas linhagens com características desejáveis que irão compor o novo genótipo, e especificamente para a mamona, interessam linhagens que transmitam alta porcentagem de flores femininas, precocidade e porte baixo. O híbrido comercial é resultado do cruzamento da linhagem feminina (planta mãe) com a linhagem masculina, fornecedora do pólen. Esse material deve ser compatível geneticamente para resultar em alta produção de semente para a comercialização (SAVY FILHO, 2005).

Contudo, existe uma carência de híbridos de mamona no Brasil, sendo que os únicos híbridos comerciais que existiam até o ano de 2008, não estão sendo mais comercializados.

Portanto, a síntese de híbridos de mamona é necessária para a agricultura tecnificada, e é notada a importância das linhagens femininas para a produção de tais híbridos. A característica de feminilidade em mamoneira já foi relatada ser complexa e ser fortemente influenciada pelo ambiente, tornando oneroso trabalhar com tal característica em termos de melhoramento.

Beltrão et al. (2001), afirma que a biologia floral da mamoneira é bastante complexa, apresentando diversas expressões de sexualidade. Segundo Shifriss (1960), as plantas de mamona podem ser classificadas em dois grupos: plantas de desenvolvimento 
normal, que são as monóicas e femininas; e aquelas que nascem femininas e ao longo do ciclo da planta se revertem, retornando ao monoicismo padrão.

Em experimentos à campo, a existência de diferentes padrões de sexualidade nas plantas de mamona se comprova. A expressão sexual em mamoneira é provada ser de natureza genética e ambiental. Fatores como estresse hídrico e alta temperatura podem favorecer a produção de flores masculinas nos racemos da mamoneira (GURGEL, 1945).

Além das plantas com racemos monóicos e plantas com racemos inteiramente pistilados, existem plantas que produzem o racemo pistilado com flores masculinas intercaladas. Essa característica tem forte controle ambiental, e Zimmerman e Smith (1966) relataram a existência de genes ambientalmente sensíveis, que governam tal característica. Plantas que apresentam o racemo feminino com flores masculinas intercaladas são de interesse para a produção de híbridos de mamona.

A expressão sexual em mamoneira é um assunto complexo e muitos resultados controversos são relatados na literatura, mas ganhos expressivos podem ser alcançados no melhoramento genético da mamoneira com o entendimento dessa característica. Para tanto, o objetivo do presente trabalho foi avaliar 80 linhagens de mamona do programa de melhoramento da Faculdade de Ciências Agronômicas da UNESP campus de Botucatu, quanto à característica de expressão sexual. 


\section{REVISÃO BIBLIOGRÁFICA}

\subsection{Origem e distribuição geográfica da cultura da mamona}

A mamona (Ricinus communis L.) é uma planta oleaginosa arbustiva e no Brasil também é denominada de carrapateira, palma-de-Cristo, enxerida e rícino. A sua origem é bastante controversa, mas alguns pesquisadores sugerem o continente asiático como provável centro de origem; outros consideram a África intertropical. Porém, a hipótese mais aceita é que esta cultura seja originária do Nordeste da África, mais precisamente da Etiópia, antiga Abissínia (HEMERLY, 1981; VEIGA; SAVY FILHO; BANZATTO, 1989; LORENZI, 2000; BELTRÃO et al., 2001; OLSNES, 2004). Seu cultivo ocorre quase na totalidade em países de climas tropicais e subtropicais; em países de clima temperado pode ocorrer, porém apresenta crescimento reduzido (DUKE, 1983).

A espécie é conhecida há bastante tempo, e existem relatos do seu cultivo há mais de 4.000 anos, para fins medicinais e também para a iluminação, com o óleo extraído das sementes de mamona (OPLINGER et al., 1997; OLSNES, 2004).

A mamoneira foi trazida para o Brasil pelos portugueses, com a finalidade de utilizar seu óleo para a iluminação e a lubrificação de eixos de carroças (AZEVEDO e BELTRÃO, 2007). A adaptação da planta de mamona em territórios brasileiros 
foi plena, sendo encontrada em praticamente em todo o território nacional (GONÇALVES et al., 1981).

\subsection{Aspectos botânicos, morfológicos e fisiológicos da mamona}

A mamona pertence à família Euphorbiaceae e ao gênero monotípico, ou seja, é a única espécie do gênero Ricinus. Na classificação botânica, a espécie Ricinus communis é considerada politípica e é dividida em seis subespécies e 25 variedades botânicas que têm áreas de ocorrências individuais ou sobrepostas, diferindo não só morfologicamente, mas também genética e ecologicamente (MOSHKIN, 1986).

A mamoneira cultivada corresponde a um arbusto, ou com menor frequiência a uma árvore, podendo chegar a 10 metros. Seu caule é cilíndrico, grosso, podendo alcançar até 30 centímetros de diâmetro na base, sua coloração externa pode variar de verde avermelhado a castanho acinzentado (RODRIGUES, 2002). As folhas são simples, alternas, glabras e verdes, sendo que essa coloração pode variar. Apresenta sistema radicular que se estende lateral e profundamente, com a parte aérea ramificada, de coloração verde ou avermelhada, apresentando ou não cera no caule, dependendo do cultivar. É uma planta monóica, que apresenta flores femininas na parte apical e flores masculinas na parte basal compondo a inflorescência (BELTRÃO et al., 2001).

A inflorescência, denominada racemo, é composta de uma ráquis, eixo em torno do qual crescem as flores femininas, na parte superior, e masculinas na inferior. A relação de flores femininas/masculinas geralmente é de 50\% a 70\%: 50\% a 30\%. Entretanto, essa relação varia grandemente, dependendo do genótipo e também do ambiente de cultivo (SAVY FILHO, 2005). A maior porcentagem de flores femininas no racemo monóico da mamoneira é um fator importante do ponto de vista agronômico, podendo ter relação com o aumento em produtividade de grãos da planta. A mamoneira apresenta protoginia, ou seja, o pistilo das flores femininas atinge a maturação cerca de 5 a 10 dias antes da maturação das anteras das flores masculinas. As flores masculinas expelem o pólen pela deiscência das anteras que se dá com violenta explosão. $\mathrm{O}$ vento é o principal agente dispersor, que arrasta o pólen para as flores femininas da mesma planta ou para as inflorescências de outras plantas (MOSHKIN, 1986). 
A flor masculina contém grande número de estames e a feminina apresenta um ovário com três lojas, desenvolvendo uma semente em cada. Os frutos, em geral, possuem estruturas semelhantes a espinhos, e em alguns casos, são inermes; uma cápsula globosa com cerca de 2,5 cm de diâmetro (SAVY FILHO, 2005). Botanicamente são do tipo baga tricoca, providos de três lojas, cada uma delas com uma semente, podendo ser deiscentes, indeiscentes ou semideiscentes, dependendo do cultivar (DUKE, 1983). A semente pode ser carunculada, ovalada, de tamanho grande, médio ou pequeno, apresentando coloração e teor de óleo variado (BELTRÃO et al., 2001).

A germinação da mamoneira é do tipo epígea, com ocorrência de 8 a 18 dias após a semeadura. Alguns cultivares podem apresentar dormência em suas sementes, e a remoção da carúncula e a posterior ruptura da casca no extremo carunculado da semente podem conduzir à quebra dessa dormência (BELTRÃO et al., 2001).

Quanto ao sistema reprodutivo, a mamoneira é considerada do tipo misto, pois ocorre tanto autofecundação dos racemos monóicos, como cruzamentos naturais. Alguns autores a consideram autógama com altas taxas de alogamia. Apesar de sua natureza reprodutiva mista, não ocorre depressão consangüínea quando é submetida a seguidas autofecundações (GURGEL, 1945).

Há poucos estudos sobre taxa de fecundação cruzada em mamoneiras, mas há relatos de que para plantas de porte anão (até $1,5 \mathrm{~m}$ ) ou médio $(2,0 \mathrm{~m})$, a taxa de fecundação cruzada é de aproximadamente $25 \%$. Estes índices podem, também, ser afetados pelo tipo de ramificação, aberta ou fechada (SAVY FILHO, 2005).

O florescimento da mamoneira é, em termos botânicos, chamado de simpodial, onde o aparecimento da inflorescência dá-se sequencialmente, com determinado intervalo entre a emissão das inflorescências primária e secundária, secundária e terciária, etc. (SAVY FILHO, 2005). Inicia no racemo principal e dentro de 10 a 12 dias, ocorre a emissão da inflorescência no ápice da haste principal e nos ramos laterais progressivamente, sempre com um intervalo definido entre a emissão da primeira e das subsequentes. O período de florescimento em mamoneira é prolongado em virtude do sincronismo de florescimento nos racemos. Podgurkaya, citado por Moshkin (1986) distinguiu seis fases no desenvolvimento de flores femininas, sendo que a $4^{\circ}$ e a $5^{\circ}$ são mais suscetíveis à polinização. $O$ estigma permanece receptivo por um período de cinco a dez dias após a antese (BRINHOLI, 1995). 
A flor masculina abre-se duas a três horas antes do amanhecer, libera grãos de pólen viáveis por um a dois dias e depois, cai ao solo. A dispersão do pólen ocorre nas temperaturas de 26 a $29^{\circ} \mathrm{C}$ e umidade relativa do ar de $60 \%$ (WEISS, 1983). As flores masculinas florescem uniformemente como as femininas, sendo o período de sua abertura mais longo do que as flores femininas (de 26 a 35 dias). O período de florescimento de uma flor termina de um a dois dias. O pólen das flores masculinas é percebido de 7 a 8 horas até 18 a 19 horas, na tarde, mas a maior parte da dispersão intensa ocorre de 9 a 13-14 horas. As anteras abrem rapidamente e ao mesmo tempo (dentro de 3 a 5 minutos) formando uma nuvem de pólen. $\mathrm{O}$ pólen mantém a viabilidade por um longo período de tempo (PODGURKAYA,1935, citado por MOSHKIN, 1986).

O hábito de crescimento é indeterminado, o que favorece o florescimento sequencial. Há indícios de que o início da floração também está relacionado com o número de internódios, de modo que quanto menor o número de internódios para a emissão da primeira inflorescência, mais precoce será a planta (TÁVORA, 1982).

A mamoneira necessita de dias longos com fotoperíodo de pelo menos 12 horas de luz por dia para produzir satisfatoriamente, sendo considerada uma espécie heliófila, apesar de se adaptar a diferentes "comprimentos de dia", mas com reflexos negativos no crescimento e produtividade (WEISS, 1983; BELTRÃO et al., 2003).

O clima propício para a mamoneira é o quente e úmido, com estações bem definidas, chuvosa na fase inicial de crescimento e seca na época da maturação e colheita dos racemos, sendo então classificada como cultura de clima tropical. Necessita de temperatura média do ar em torno de $25^{\circ} \mathrm{C}$, variando entre $20^{\circ} \mathrm{C}$ e $30^{\circ} \mathrm{C}$ e altitude de pelo menos $300 \mathrm{~m}$, sendo seu ótimo de $650 \mathrm{~m}$ de altitude. É considerada bastante resistente à seca e não tolerante a salinidade (BELTRÃO e CARDOSO, 2006). Temperaturas superiores a $40^{\circ} \mathrm{C}$ podem provocar aborto de flores, reversão sexual e reduzir substancialmente o teor de óleo nas sementes (BELTRÃO, 1999). A altitude não é o fator limitante ao desenvolvimento da mamoneira, mas influencia fatores como nebulosidade, umidade e pressão de oxigênio, e principalmente a temperatura, a qual tende a decrescer à medida que a altitude aumenta. A temperatura tem grande impacto sobre a fotossíntese e respiração da planta, pois influencia diversas reações bioquímicas ligadas a esses dois processos fisiológicos (TAIZ; ZEIGER, 
2004). No estado do Rio Grande do Sul, em áreas com altitude quase ao nível do mar, a mamoneira se desenvolve satisfatoriamente.

A mamoneira necessita acumular entre 2.000 e 3.800 graus-dias para alcançar rendimentos viáveis economicamente (MOSHKIN, 1986b).

A faixa ideal de precipitação para a mamoneira produzir satisfatoriamente situa-se entre $750 \mathrm{~mm}$ e $1.500 \mathrm{~mm}$, com um mínimo de $600 \mathrm{~mm}$ a $750 \mathrm{~mm}$ durante o ciclo cultural; de preferência, a época de plantio deve ser ajustada para que a planta receba de $400 \mathrm{~mm}$ a $500 \mathrm{~mm}$ até o início da floração (TÁVORA, 1982). A falta de água no solo, mesmo que na fase de maturação dos frutos, implica em sementes com baixo peso e teor de óleo (HEMERLY, 1981).

A mamoneira cresce e floresce sob uma ampla extensão de condições climáticas, embora sua habilidade para produzir satisfatoriamente seja limitada pela incidência de excessos de umidade, frio intenso ou temperaturas muito elevadas durante o florescimento. Dentre os estádios de desenvolvimento, o período reprodutivo é o mais afetado e o que mais limita a produtividade da cultura, quando as condições ambientais são desfavoráveis. (WEISS, 1971; WEISS, 1983).

A cultura da mamona se adapta às mais distintas classes de solos, entretanto, solos excessivamente úmidos e com problemas de drenagem, bem como áreas sujeitas a inundações prolongadas no período chuvoso, devem ser evitadas, pelo fato de a mamoneira ser sensível ao excesso de umidade (TÁVOORA, 1982). Portanto, os melhores solos para a sua exploração são os profundos, bem drenados, de textura média, ricos em matéria orgânica, férteis sem problemas de salinidade. Segundo Savy Filho (1999a) o pH ideal do solo para a cultura da mamona é entre 5,5 e 6,5. Vale ressaltar que devido ao rápido crescimento, ocorre uma grande extração de nutrientes do solo, apresentando-se como muito exigente em termos de fertilidade (HEMERLY, 1981).

\subsection{Aspectos socioeconômicos da cultura da mamona}

Desde a década de 90, onde mudanças climáticas drásticas resultaram em uma forte preocupação com as questões ambientais e, associada a elas, o aumento no preço do petróleo, as fontes energéticas mundiais vêm sendo modificadas. Na tentativa de se obter 
fontes para atender a demanda energética, pesquisas vêm sendo realizadas, buscando opções ambientalmente corretas e economicamente viáveis. Umas das opções apontadas como fonte energéticas são os óleos vegetais, e é nesse contexto que se insere a importância da cultura da mamona, devido ao óleo vegetal, principal produto extraído de suas sementes. O maior apelo da mamona nesse contexto é o social, pois grande parte do seu cultivo é baseado na agricultura familiar.

O Brasil foi durante décadas, o maior produtor mundial de mamona em grão e maior exportador de óleo. Esse cenário foi alterado, na década de 80, quando a Índia e a China superaram o Brasil, ocupando respectivamente o primeiro e segundo maiores produtores de mamona do mundo. $\mathrm{O}$ alto custo da colheita manual necessária à cultura fez com que o Brasil perdesse o posto de maior produtor e exportador do óleo de mamona. Além do alto custo da colheita manual, a cultura da mamona perdeu frente à concorrência com outras culturas em virtude da falta de incentivo ao produtor, que não era bem pago por sua matériaprima. Como consequência, a produção de mamona apresentada um baixo nível tecnológico, com o uso de sementes que não eram melhoradas e ausência de melhores sistemas de preparo do solo, semeadura e colheita. Além disso, a comercialização era dificultada pela presença dos intermediários na cadeia produtiva da mamona até sua industrialização, o que prejudicava o produtor rural (SAVY FILHO et al., 1997).

Segundo Azevedo e Beltrão (2007), no período compreendido entre 1978 e 2004, a Índia, China e o Brasil se mantiveram como os principais produtores mundiais de mamona em baga, tanto em termos de área colhida quanto em quantidade produzida

A importância da cultura da mamona teve seu retorno, com as especulações acerca do óleo extraído de sementes e sua aplicação como combustível de origem renovável, o "biodiesel”. Com o Programa Nacional de Produção e Uso do Biodiesel, que autorizou a adição de $2 \%$ de biodiesel (B2) ao diesel em 2005, diversos estados do Nordeste tiveram grande incentivo do governo federal para a expansão da produção de mamona, embasada principalmente na agricultura familiar (SAVY FILHO, 2005). Esses programas de incentivo à produção de oleaginosas têm como objetivo a expansão das áreas de cultivo da mamona no Brasil, não só na região Nordeste, mas também nas regiões CentroOeste, Sudeste e até mesmo Sul do país, o que leva a concluir que o desenvolvimento de 
novos genótipos, adaptados a cada uma das regiões, serão indispensáveis para o sucesso da cultura.

Contudo, o óleo extraído das sementes de mamona possui uma ampla utilização na indústria química, sendo o "biocombustível” somente uma de suas inúmeras aplicações. Devido à extraordinária capacidade de adaptação e a multiplicidade de aplicações industriais do óleo de suas sementes, a mamoneira inclui-se entre as oleaginosas tropicais de maior valor econômico e estratégico (HEMERLY, 1981).

O óleo de mamona é um dos mais versáteis da natureza, de utilidade só comparável a do petróleo, com a vantagem de ser renovável. A singularidade do óleo de mamona dá-se em virtude de sua composição quase que exclusiva (cerca de 90\%) do ácido graxo ricinoléico. A elevada viscosidade e estabilidade de tal produto são mantidas em larga faixa de condições de temperatura. É matéria-prima para mais de 400 produtos, sendo usado nas indústrias farmacêutica, cosmética e alimentícia (AZEVEDO et al., 1998; AMARAL, 2003).

Devido à alta capacidade de reações químicas dada pelo ácido graxo ricinoléico, o óleo de mamona tem larga aplicação na fabricação de tintas, vernizes, detergentes, inseticidas, nylon, resinas de plástico, lubrificantes, tubos especiais para irrigação, chapas e engrenagens, aditivos para combustível, bactericidas, fungicidas, produtos sintéticos, fluidos especiais para transmitir pressões hidráulicas, graxas para navio e aviões, espumas plásticas e para-choques em automóveis, próteses humanas para coluna vertebral, crânio, mandíbula, dentes e mamas (CARVALHO, 1997; SÃO PAULO,1998; GIBELLI, 2001; FILKAUSKAS, 2001; SANCHES, 2003).

Em termos quantitativos, o óleo de mamona é mais utilizado na fabricação de tintas, vernizes, cosméticos e sabões. Deve-se mencionar que as fibras em cuja composição entra o óleo de mamona são antitóxicas e antialérgicas. Quando processado, destaca-se seu uso como lubrificantes (AZEVEDO e BELTRÃO, 2007).

Outro importante aspecto da cultura de mamona é o aproveitamento das cascas dos frutos, que estimativamente podem atingir até $2.000 \mathrm{~kg} \mathrm{ha}^{-1}$, com a possibilidade de serem utilizadas como adubo orgânico (FREIRE, 2001). A torta de mamona, que é o subproduto da prensagem das sementes para obtenção do óleo, pode ser utilizada como adubo orgânico nas culturas de café, citrus, cana-de-açúcar, hortaliças, frutífera e conhecida 
como produto que apresenta efeito nematicida (SAVY FILHO et al., 1999a), e também empregada na alimentação animal, após o processo de desintoxicação.

A produção de mamona no Brasil concentra-se no Nordeste, tradicionalmente produzida em pequenas e médias propriedades, possuindo importante valor social como geradora de renda e empregos no campo. O estado da Bahia possui $75 \%$ de sua área plantada com a cultura da mamona, consorciando-a com feijão de corda (Vigna unculata) ou de arranca (Phaseolus vulgaris). Em virtude da elevada capacidade de resistência à seca, a mamoneira é apta a ser explorada economicamente no semiárido brasileiro, que corresponde a mais de $75 \%$ da área total do Nordeste, representando 18\% do território nacional (BELTRÃO, 2001).

A forte expansão da cultura de mamona e com o valor agregado da sua principal matéria-prima sendo referência na economia e no setor ambiental, o que se busca é aumentar a tecnologia no cultivo. Do ponto de vista de melhoramento genético, é necessário o conhecimento de que, apesar da rusticidade da cultura da mamona, o baixo nível tecnológico resulta em baixas produtividades e pouco retorno econômico. É necessário que o produtor de mamona, faça uso de tecnologias, como sementes tratadas, uso de adubos, manejo integrado de pragas e doenças, e principalmente, uso de genótipos adaptados à região de cultivo e produtivos.

\subsection{Melhoramento genético da mamona}

No Brasil, há programas de pesquisa e desenvolvimento com a cultura da mamoneira sendo realizados nos Estados de São Paulo, Bahia e Paraíba. As primeiras pesquisas com o melhoramento genético da mamona no Brasil foram realizadas no Instituto Agronômico, em Campinas-SP, no ano de 1936, e desde então vem desenvolvendo tecnologia de produção para a cultura da mamoneira (SAVY FILHO, 1999a), com a implantação e execução do Plano Geral dos Trabalhos em Execução nas Seções de Genética e Plantas Oleaginosas do Instituto Agronômico de Campinas do Estado de São Paulo (KRUG e MENDES, 1942).

No estado de São Paulo, algumas cultivares merecem destaque, a exemplo da "Guarani", por seu uso e potencial. A cultivar é resultado do cruzamento das 
cultivares "Campinas" e "Preta" em 1964, possuindo porte médio com $180 \mathrm{~cm}$ a $200 \mathrm{~cm}$ de altura e ciclo de aproximadamente 180 dias. Seus frutos apresentam espinhos e têm caráter indeiscente com produtividade média de $3.090 \mathrm{~kg}^{-h^{-1}}$ (HEMERLY, 1981). Existem populações derivadas do cultivar Guarani, denominadas Guarani Comum, que foram multiplicadas por produtores sem os devidos cuidados para manutenção da pureza genética e produção de sementes. Esse procedimento indiscriminado possibilitou cruzamentos naturais com outras cultivares e com mamoneira comum, gerando assim variabilidade genética para diversas características, inclusive altura de plantas (ZANOTTO et . al, 2004).

Outra importante cultivar é a AL-Guarany 2002, que foi lançada pelo Departamento de Sementes Mudas e Matrizes da Coordenadoria de Assistência Técnica Integral - CATI, Campinas (SP). É um material obtido por seleção massal da cultivar Guarani e é comercializada desde 2002 (SAVY FILHO, 2005).

Um vasto conhecimento tecnológico sobre a cultura da mamona tem sido disponibilizado aos produtores rurais pelo Instituto Agronômico (IAC), com o lançamento de cinco cultivares: Campinas, IAC-38, IAC-80, IAC-226 e Guarani, as três últimas em comercialização e cultivadas em todo território brasileiro.

A cultivar IAC-38 apresenta porte anão, frutos deiscentes, boa capacidade produtiva e ampla adaptação às condições edafoclimáticas do Estado de São Paulo (SAVY FILHO; BANZATTO, 1993).

O Instituto Agronômico (IAC), de Campinas, para atender ao agronegócio da mamona no Brasil, lançou a nova cultivar, a IAC 2028. A cultivar possui elevado potencial produtivo, entre 1.500 e $2.800 \mathrm{~kg} \mathrm{ha}^{-1}$ nas condições do Estado de São Paulo, ciclo precoce (150 a 180 dias) até a colheita dos racemos terciários e quaternários, teor de óleo de $47 \%$ e frutos indeiscentes. Foi obtida por meio da hibridação artificial entre a linhagem L881, desenvolvida por seleção massal dentro da cultivar IAC-38, e a progênie H34.

$\mathrm{Na}$ Bahia a Empresa Baiana de Desenvolvimento Agrícola S/A (EBDA) também trabalhou com a cultura da mamoneira, tendo desenvolvido algumas cultivares. As cultivares identificadas com a sigla SIPEAL foram lançadas por essa empresa.

A EMBRAPA, através do Centro Nacional de Pesquisa do Algodão (CNPA), localizado em Campina Grande, Paraíba, desenvolve projeto para a cultura da mamoneira, visando tecnologia de produção para a região semiárida do Nordeste, e, por meio 
do CENARGEN, mantém um Banco Ativo de Germoplasma de Mamona, com cerca de 1.000 acessos disponíveis para intercâmbio (SAVY FILHO, 1999a).

Como resultado dessa atividade, o CNPA lançou novas cultivares de mamona, a BRS 149 (Nordestina) em 1998 e a Paraguaçu em 1999, ambas de porte alto e adaptado às condições tecnológicas do pequeno e médio produtor, para as condições edafoclimáticas da Bahia, Pernambuco e Paraíba (EMBRAPA, 1998).

Entre os principais objetivos dos programas de melhoramento da mamoneira estão o aumento em produção, a uniformidade, o porte anão de plantas, resistência a doenças causadas por Fusarium, Botrytis, Alternaria e Xanthomonas; caráter para frutos indeiscentes no campo, para reduzir perdas na colheita e sementes de tamanho médio, uniformes e com alto teor de óleo (SAVY FILHO, 1999a). Essas características agronômicas são consideradas ideais, para a obtenção de um novo genótipo (cultivar ou híbrido), de extrema importância para o aumento do rendimento econômico e industrial da cultura da mamoneira.

Segundo Laureti e Brigham (1987), a produtividade é uma característica complexa, pois depende da capacidade de absorção de água e nutrientes e da eficiência fotossintética. Os componentes da produtividade da mamoneira são número de cápsulas/ racemo, número de racemos/ planta e peso unitário da semente. A seleção de plantas pode alterar todos esses caracteres, contudo o caráter produtividade é de natureza quantitativa, governada por muitos genes, sendo portanto mais oneroso de se trabalhar.

A porcentagem de flores femininas nos racemos monóicos das plantas de mamona é uma característica que influencia diretamente a produtividade de grãos, sendo portanto uma característica importante para o melhoramento da mamoneira. O objetivo é aumentar a porcentagem de flores femininas. Além da produtividade, as linhagens pistiladas de mamona são importantes para a produção de híbridos comerciais.

O Programa de Melhoramento Genético da Faculdade de Ciências Agronômicas, Campus de Botucatu - UNESP estuda a cultura da mamona, com o principal objetivo de obter genótipos produtivos, com porte adequado à colheita mecanizada e adaptados às principais regiões produtoras de mamona. Uma das linhas de pesquisa do programa da FCA-UNESP é o estudo da herança da expressão sexual em mamoneira, com enfoque na obtenção de linhas femininas para a produção de híbridos e também cultivares com 
maiores porcentagens de flores femininas nos racemos, sendo estas mais produtivas. Do programa de melhoramento de mamona da FCA-UNESP, já foram publicadas teses e dissertações (MYCZKOWSKI, 2006; BERTOZZO, 2009) com o tema da expressão sexual em mamona, colaborando sobremaneira com o estudo nessa área.

\subsection{Florescimento e expressão do sexo em mamona}

A mamoneira é uma planta de crescimento indeterminado, e sua ramificação principal e as secundárias terminam em uma inflorescência. As folhas se desenvolvem de cada nó e cada axila da folha é capaz de diferenciar em um racemo. O número de nós até o racemo primário é uma característica que corresponde a precocidade da planta, sendo que quanto maior o número, mais tardia é essa planta. O florescimento da mamona é chamado botanicamente de simpodial, o aparecimento da inflorescência dá-se sequencialmente, com determinado intervalo entre a emissão das inflorescências. A inflorescência é constituída pela ráquis, eixo em torno do qual crescem as flores femininas na parte superior e masculinas na inferior, em proporções que variam bastante (SHIFRISS, 1956). A inflorescência padrão é um racemo monóico e a mamoneira é potencialmente uma planta perene, mas as variedades na atualidade são cultivadas como anuais. Apresenta a reprodução sexual denominada mista, já que é autógama com alta taxa de alogamia, que favorece os estudos genéticos na planta.

A mamoneira apresenta além da expressão monóica de seu racemo outros tipos de expressão sexual, tais como: racemo monóico com flores masculinas intercaladas no ápice, racemo monóico com flor hermafrodita no ápice, racemo inteiramente feminino, que podem ser estável geneticamente (sem reversão sexual) ou instável geneticamente (que apresentam reversão sexual). As plantas com racemos estritamente com flores femininas podem apresentar também flores masculinas intercaladas (no ápice, na base, ou no racemo todo) e flor hermafrodita (no ápice ou na base).

Segundo Beltrão et al. (2001), a biologia floral da mamoneira é muito complexa, apresentando diversas expressões de sexualidade, com as flores masculinas e femininas localizadas em uma mesma inflorescência, mas em posições diferentes. 
As plantas de mamona são definidas como de desenvolvimento normal ou com reversão sexual. As de desenvolvimento normal podem ser aquelas com flores femininas e masculinas ou apenas flores femininas, também chamadas de pistiladas e as que possuem reversão sexual são aquelas que apresentam inflorescências que nascem femininas, mas acabam tornando-se masculinas ao longo de sua ontogenia (SHIFRISS, 1960).

Popova e Moshkin (1986) comprovaram a existência de seis principais tipos de expressão sexual em mamoneira: as fêmeas estáveis (que produzem apenas flores femininas); as fêmeas instáveis (onde o cacho principal tem apenas flores femininas, mas os demais cachos podem ter flores masculinas); as inclinadas para fêmeas (poucas flores masculinas na base do cacho); mista (pequeno número de flores masculinas entremeadas nas flores femininas); monóicas comuns e macho.

A expressão do sexo em mamoneira é influenciada por fatores de natureza genética e fatores de ordem ambiental. Estudos comprovam que plantas submetidas a estresse hídrico aumentam sua porcentagem de flores masculinas, assim como altas temperaturas provocam o mesmo efeito. Em contrapartida, solos férteis ou bem balanceados favorecem o aumento da porcentagem de flores femininas (GURGEL, 1945).

Beltrão et al. (2001), confirma que os fatores que afetam a expressão do sexo são: idade da planta e dos racemos, pois os primeiros apresentam maior quantidade de flores femininas, comprimento do dia, no qual dias curtos aumentam a expressão de flores femininas, temperaturas elevadas favorecem a ocorrência de maior número de flores masculinas e poda que pode promover o surgimento de flores femininas. Possivelmente, a altitude influencie a expressão sexual de forma indireta através da temperatura, pois geralmente maiores altitudes estão associadas à menor temperatura, o que favorece o aumento de flores femininas. Savy Filho, (1999a), ressalta que deficiência hídrica e alta temperatura induzem a formação de flores masculinas e solos férteis estimulam flores femininas.

Segundo Shifriss (1956), a tendência sexual em mamona é também governada por fatores não genéticos, onde plantas jovens, especialmente em racemos primários, em atividade vegetativa moderada, temperatura moderada e alto nível de nutrição têm tendências fortes para a sexualidade feminina. Quando intercruzadas, essas plantas geram na descendência, plantas femininas que retornam rapidamente ao monoicismo, evidenciando um estado temporário de feminilidade. Plantas em declínio ou velhas, com alta atividade 
vegetativa, e altas temperaturas e em solos com baixo nível de nutrição são fortemente influenciadas para a sexualidade masculina.

A definição da expressão sexual é um processo complexo, que envolve muitos hormônios entre eles as giberelinas e citocininas, que são os principais atuantes no metabolismo fisiológico da planta. As citocininas agem favorecendo a ocorrência de flores femininas, enquanto que as giberelinas aumentam a porcentagem de flores masculinas. Khryanin (2002) relata uma série de plantas em que esse comportamento foi observado: Begonia hybridis, Cucumis sativus, Mercurialis annua, Zea mays e Buchloe dactyloides. Porém, há relatos opostos em que se afirma que as giberelinas favorecem flores femininas em mamona (POPOVA e MOSHKIN, 1986).

Outros hormônios vegetais também podem estar relacionados à expressão sexual, pois algumas plantas podem ser influenciadas pelo tratamento com auxinas, com evidências de que o balanço entre auxinas e giberelinas seja crucial para a expressão sexual. O etileno também apresenta grande influência sobre a feminilização de plantas e este efeito pode ser devido a sua estreita influência sobre as auxinas e citocininas. Quanto ao ácido abcísico, há evidências de que ele promove a feminilização, mas os relatos são ainda muito contraditórios. Sua ação parece se dar através da inibição da atividade das giberelinas (KHRYANIN, 2002).

Solanki e Joshi (2000), estudando um dialelo com quatro linhas femininas e quatro monóicas, em seis ambientes e sob duas estações, descobriram que efeitos gênicos aditivos e epistáticos são responsáveis pela expressão do sexo nos racemos primários, secundários e terciários de mamona (com a maior parte de efeitos aditivos). Os efeitos aditivos foram os que contribuíram para o caráter da feminilidade. $\mathrm{O}$ efeito de genes dominantes parece não ser bem elucidado se favorece ou prejudica a feminilidade. As interações epistáticas contribuíram em alguns cruzamentos. Há predominância de genes aditivos e epistáticos para a porcentagem de flor feminina. Observa-se que o florescimento e a expressão do sexo em mamoneira é um aspecto complexo, pois apresenta muitas variantes para a inflorescência padrão. Os fatores para essas variantes são de ordem genética e ambiental, os quais serão detalhados mais adiante. 


\subsubsection{Herança da expressão sexual}

\section{a) Monóico padrão}

É denominado sistema convencional ou formas mendelianas ou geneticamente estáveis (incluem os monóicos normais e raros mutantes femininos recessivos) (SHIFRISS, 1960).

As plantas desse sistema são de expressão sexual persistentes, ou seja, se ocorre alguma variação no monoicismo ou feminismo de tais plantas, essa variação é ontogenicamente reversível. A relação de flores femininas e masculinas nos racemos monóicos é a tendência sexual. As condições ambientais influenciam na tendência feminina ou masculina em mamona. Condições ambientais favoráveis resultam em uma maior tendência feminina, como poda ou remoção de frutos imaturos no racemo primário, fazendo com que produzam racemos subsequentes femininos.

$\mathrm{O}$ monoicismo é governado por dois grupos principais de genes. $\mathrm{O}$ primeiro grupo consiste de genes qualitativos e estes determinam os tipos de flores, com estames e pistiladas, que podem ser diferenciados potencialmente pela inflorescência. $\mathrm{O}$ segundo grupo consiste de poligenes, e estes determinam o nível de concentração de uma substância que canaliza a ação dos genes qualitativos. Desse modo, os poligenes são responsáveis pelo gradiente de diferenciação. As plantas monóicas e femininas podem ser tanto AAGG aaGG (A para flores com estames, G para flores pistiladas) ou MoMo ou momo (Mo para flores tanto com estames quanto pistiladas, mo para flores predominantemente pistiladas) (SHIFRISS, 1960).

\section{b) Monóicas com flores masculinas intercaladas no ápice}

Ainda sobre as plantas monóicas, existem aquelas que apresentam flores masculinas apicalmente intercaladas entre as femininas. Dentro desse grupo existem as ambientalmente sensíveis (que são intercaladas dependendo do ambiente de tendência feminina ou masculina) e as resistentes (sempre intercaladas). Zimmerman e Smith (1966) mostraram que se trata de genes modificadores recessivos (id). Esse gene sozinho não 
determina a característica de diferenciação sexual, provavelmente ela é manifestada na presença de fatores para distribuição uniforme de flores pistiladas, fatores de determinação de fêmeas, e genes id para flores estaminadas intercaladas.

\section{c) Femininas estáveis geneticamente (sem reversão sexual)}

Além de plantas de mamona com o racemo monóico padrão, existem na natureza algumas plantas classificadas como femininas (CLAASSEN e HOFFMAN, 1949) já que possuem os seus racemos inteiramente coberto por flores femininas, não havendo nenhuma flor masculina. Essas plantas são de ocorrência rara na natureza, já que elas nunca produzem racemos monóicos. Um exemplo é a fêmea Nebraska 145-4 (SHIFRISS, 1956). Shifriss (1960) relata que a característica de feminilidade do sistema convencional ou formas mendelianas, é governada por um gene recessivo.

Em suas pesquisas, Claassen e Hoffman (1949) afirmam que a maior parte das plantas que tinham $100 \%$ de flores pistiladas pelo menos nos racemos primários, continuou a produzir $100 \%$ de flores pistiladas em seus racemos. Aproximadamente 2/3 das plantas com 90 a 99\% de flores pistiladas no primeiro racemo, produziu mais tarde racemos com $100 \%$ de flores pistiladas. Poucas plantas que tinham 90 a $100 \%$ de flores pistiladas produziram mais tarde racemos que tinham uma porcentagem normal de flores pistiladas e flores estaminadas. A conclusão do trabalho é que a herança não é consistente para plantas com 90 a $99 \%$ de flores pistiladas e que plantas com 90 a $100 \%$ de flores pistiladas expressam o caráter em intensidades diferentes.

A expressão do caráter pistilado é influenciada por modificação de gene e fatores ambientais. A produção de semente híbrida de mamona pode ser feita usando linhas de plantas com 90 a 100\% de flores pistiladas e que se reproduzam; ou por plantas com $100 \%$ de flores pistiladas, segregando em uma razão de uma planta monóica heterozigota e uma dióica. A herança da quase totalidade de flor feminina em mamoneira é controlada por um gene recessivo principal (CLAASSEN e HOFFMAN, 1949).

Laureti e Brigham (1987), conceituaram e discutiram os resultados obtidos por outros autores que estudaram a machoesterilidade. Na conclusão eles perceberam que na mamoneira não ocorre a machoesterilidade e sim formas com ausência de flores 
masculinas. São conhecidos três tipos de plantas femininas: N, S e NES. No tipo $\mathrm{N}$ a feminidade da planta é dada pela homozigose de alelos recessivos (ff). Em heterozigose (Ff) as plantas são normais, ou seja, monóicas. A manutenção da feminidade é feita com cruzamento Ff x ff, obtendo-se na descendência, 50\% de plantas femininas. Na produção do híbrido $\mathrm{F} 1$, é necessária a eliminação das plantas monóicas antes da antese. O tipo $\mathrm{S}$ caracteriza-se pela reversão de plantas, inicialmente femininas, para o tipo monóico, em qualquer fase do ciclo após a emissão do racemo primário. A seleção é realizada com o cultivo isolado destas plantas, deixando reproduzir as plantas femininas e as plantas que revertem o mais tarde possível. Em função da pressão de seleção e do número de ciclo de seleção, é possível a obtenção de plantas com 60 a 95\% de plantas inicialmente femininas. Entretanto, a herança do caráter não é plenamente elucidada, mas considera-se que dependa de um sistema poligênico, com efeito de dominância e epistasia. Já o tipo NES tem flores masculinas entre as flores femininas (interspersed), e o gene para feminismo é acompanhado por um gene modificador (s), que pode apresentar modificação em função da temperatura em que se cultiva a planta. Tal gene independe do gene $(f)$ e se expressa no interior do racemo feminino com flores masculinas, esparsas, em número variado, permitindo a polinização com pólen de plantas inicialmente femininas e geneticamente femininas e, também, a autofecundação.

\section{d) Femininas instáveis geneticamente (de reversão sexual)}

Existem na natureza as plantas de mamona femininas instáveis geneticamente, que apresentam reversão sexual. As plantas de reversão sexual, diferentes da monoicia normal, desenvolvem-se inicialmente racemos de primeira ordem inteiramente femininos, e ao longo do ciclo de desenvolvimento da planta, racemos monóicos vão se desenvolvendo nas mais altas ordens, como a variedade "Gamadon" (SHIFRISS, 1956). A ordem com que tais racemos monóicos se desenvolvem também é muito variável de cada planta, sendo que quanto mais cedo a planta retorna ao monoicismo, menos feminina ela é denominada.

A frequência de fêmeas dominantes é baixa na natureza, em populações selvagens, porém em variedades cultivadas, devido a domesticação e seleção, essa frequência pode ser alta. A maior parte dessas plantas é de reversão sexual. Mesmo as fêmeas 
dominantes provaram ser geneticamente instáveis, ou seja, variam muito a proporção de fêmeas na descendência imediata. Quanto mais precocemente essa planta fêmea se reverter, ou seja, se ela se reverter ao monoicismo nos racemos logo de primeiras ordens, na descendência ela deixará mais plantas monóicas do que femininas, ou exclusivamente monóicas.

O uso de substâncias que promovam o aumento na síntese de auxina pode ser utilizado para aumentar a porcentagem de flores femininas em mamona. Isso se deve possivelmente pela auxina reduzir a síntese de AIA oxidase ou pode ser devido à síntese de mais auxinas (KUMAR, 1981). Essas substâncias devem ser utilizadas na fase vegetativa, todavia pouco se conhece sobre o estágio de diferenciação floral em mamoneira. As plantas femininas de mamona induzidas pelo ambiente estão no que chamamos de estado temporário de feminilidade, e retornam ao monoicismo quando o ambiente é alterado, e se autofecundadas geram plantas monóicas.

\section{e) Femininas com flores masculinas intercaladas}

Algumas das plantas femininas de mamona apresentam o racemo inteiramente feminino, e em determinado momento, por ocasião do ambiente, desenvolvem-se entre as flores femininas, algumas flores masculinas, mais tardias. A distribuição dessas flores masculinas pode ser mais evidente no ápice; na base; ou distribuída igualmente no racemo inteiro, mas sempre intercaladas as flores femininas (SHIFRISS, 1956). É verificado que altas temperaturas podem desencadear o aparecimento de tais flores masculinas intercaladas.

George e Shifriss (1967) relataram sobre dois genes independentes, idl e id2, e observaram que a ação combinada desses dois genes era quem expressava a característica de flores estaminadas intercaladas sob várias formas de condições ambientais. Essa expressividade é bastante variável, e medida pela ocorrência de tais flores nos racemos normais. O nível de expressividade de flores estaminadas intercaladas parece depender da dosagem dos genes id, em seus locos, bem como das condições ambientais.

Sob condições ambientais que favoreçam uma forte expressão masculina ocorrem flores intercaladas com estames, na porção pistilada superior de racemos normais assim como em inflorescências pistiladas em plantas com reversão sexual. As flores intercaladas permitem que as plantas com reversão sexual se reproduzam mesmo antes de 
haver a reversão ao monoicismo normal. A reversão de fenótipos não é simultânea em todos os racemos, porém depois é irreversível. Outro aspecto importante é que plantas revertidas que retornam mais tardiamente ao monoicismo produzem uma maior proporção de plantas femininas em suas progênies (SHIFRISS, 1956).

Zimmerman e Smith (1966) relataram sobre genes sexuais ambientalmente sensíveis. Esses genes se expressam pela presença de flores estaminadas espalhadas pela porção pistilada do racemo. Sob altas temperaturas ocorre um aumento de flores estaminadas nos racemos normais da mamoneira. Estudando tais genes ambientalmente sensíveis, eles concluíram que a característica da sexualidade de flores estaminadas intercaladas as flores pistiladas é governada por um sistema de poligenes.

Esse caráter de flores estaminadas intercaladas mostra ser governado por poligenes modificadores recessivos e com forte influência do ambiente, sendo independente do gene(s) para o feminismo. Porém os genes id sozinhos não determinam a característica de diferenciação sexual, provavelmente ela é manifestada na presença de fatores para distribuição uniforme de flores pistiladas, fatores de determinação de fêmeas, e genes $i d$ para flores estaminadas intercaladas. Os genes para flores estaminadas intercaladas apresentam uma seletiva vantagem sob condições naturais, já que na presença desses genes, essas plantas conseguem se reproduzir.

Patel (1986) realizou um trabalho de indução da formação de flor masculina em linhas femininas de mamona em condições de baixas temperaturas, removendo as flores femininas dos racemos primários, secundários e terciários. A remoção aumentou em 30 vezes o aparecimento de flores estaminadas intercaladas, em virtude do balanço hormonal. O ambiente é fator importante na seleção de plantas de mamona e na obtenção de híbridos. Segundo Lavanya (2002), na Índia os híbridos são produzidos pelo sistema convencional que consiste no plantio de 20-25\% de linhas monóicas, fornecedoras de pólen, em meio a linhas femininas. Porém, com o alto custo e a dificuldade do "rouguing" de plantas monóicas antes da antese, passou-se a utilizar os genes ambientalmente sensíveis em progênies fêmeas revertidas tardiamente, alcançando uma pureza genética mais alta. $\mathrm{O}$ inconveniente é entender o ambiente, já que esse método tem que ser feito no verão, e a alta temperatura e os ventos dessecantes reduzem a produção de semente. O caráter é influenciado por temperatura elevada, precipitação e comprimento do dia, à semelhança dos genes instáveis que causam a 
reversão sexual em mamoneira. Nesse trabalho, não conclui que se tratava de dois genes (idl e id2), já que houve muitas variações. Plantas com menores variações na proporção de flores estaminadas intercaladas podem ser governadas por eles.

O estudo da interação entre fatores de feminilidade e genes ambientalmente sensíveis é de grande importância, do ponto de vista agronômico. As plantas de mamona com a característica intercalada são mais produtivas do que aquelas com gradiente monóico, e essas plantas podem ser usados na produção de sementes híbridas de mamona.

Os programas de melhoramento genético da mamoneira visam à obtenção de cultivares mais produtivas, de porte médio para facilitar a colheita, precoces e com elevados teores de óleo. Dentre todas as características citadas, sem dúvida a produtividade é a de maior relevância, seja por seu apelo econômico ou pela maior dificuldade em se estabelecer bases genéticas para esse caráter poligênico. Em se tratando da cultura da mamoneira, pesquisas e estudos devem ser exaustivamente realizados para que se conheça com exatidão a herança do caráter de totalidade de flores pistiladas, para que se alcance eficiência nos programas de melhoramento. 


\section{MATERIAL E MÉTODOS}

\subsection{Localização e caracterização da área experimental}

O experimento foi desenvolvido no ano agrícola de 2008, no período de abril a dezembro, em dois locais: no município de São Manuel - SP, na Fazenda Experimental São Manuel e no município de Botucatu-SP, na Fazenda Experimental Lageado, ambos pertencentes à Faculdade de Ciências Agronômicas, no Campus de Botucatu - UNESP.

O município de São Manuel está localizado a latitude $22^{\circ} 43^{\prime} 52^{\prime}$ ' sul e à longitude $48^{\circ} 34^{\prime} 14^{\prime}$, , com altitude ao redor de 709 metros. O solo onde foram conduzidos os experimento está classificado como Latossolo Vermelho-Amarelo- Fase Arenosa de baixa fertilidade natural. O município de Botucatu está localizado.a $770 \mathrm{~m}$ de altitude, 22 $42^{\circ} 31^{\prime \prime}$ de latitude sul e $48^{\circ} 25^{\prime}$ 37" longitude Oeste. O solo da Fazenda Experimental Lageado, no município de Botucatu é classificado como Nitossolo Vermelho Distroférrico (EMBRAPA, 1999). O clima de São Manuel é classificado, segundo a classificação de Köeppen, como sendo do tipo Cwa, tropical úmido, com inverno seco (junho a agosto) e verão chuvoso (dezembro a fevereiro). O clima de Botucatu, de acordo com a classificação de Koppen é do tipo Cfa, subtropical, com verões quentes e úmidos, e invernos frios e secos. 


\subsection{Material}

O material utilizado no presente trabalho foi constituído de 80 linhagens de mamona de diferentes origens, as quais foram selecionadas para maior porcentagem de florescimento feminino no racemo primário. Entre elas estão materiais oriundos de países como a China e Israel, um híbrido comercial (Sara) e linhagens desenvolvidas pelo Programa de Melhoramento de Mamona da Faculdade de Ciências Agronômicas da UNESP campus de Botucatu. A designação das linhagens encontra-se na Tabela 1.

Tabela 1. Relação das linhagens de mamona avaliadas nos experimentos de Botucatu-SP e São Manuel-SP, na safrinha de 2008.

\begin{tabular}{|c|c|c|c|c|c|c|}
\hline 01 & MRZ.03 & CV.1 & SM 2008 & 41 & Parc. 13 x Parc.13 & SM 2008 \\
\hline 02 & MRZ.03 & CV.2 & SM 2008 & 42 & Parc. 13 x Parc.13 & SM 2008 \\
\hline 03 & MRZ.03 & CV.4 & SM 2008 & 43 & Parc. 25 x Parc. 27 & SM 2008 \\
\hline 04 & MRZ.03 & CV.5 & SM 2008 & 44 & Parc. 25 x Parc. 27 & SM 2008 \\
\hline 05 & MRZ.03 & CV.7 & SM 2008 & 45 & Parc.31 x Parc.31 & SM 2008 \\
\hline 06 & MRZ.03 & CV.8 & SM 2008 & 46 & Parc.17.1 & SM 2008 \\
\hline 07 & MRZ.03 & CR.17 & SM 2008 & 47 & Parc.17.1 & SM 2008 \\
\hline 08 & MRZ.03 & CR.18 & SM 2008 & 48 & Parc.17.1 & SM 2008 \\
\hline 09 & MRZ.03 & CR.21 & SM 2008 & 49 & Parc. 17.4 x 17.4 & SM 2008 \\
\hline 10 & MRZ.03 & CR.22 & SM 2008 & 50 & Parc.17.4 x 17.4 & SM 2008 \\
\hline 11 & MRZ.03 & CR.28 & SM 2008 & 51 & Parc. 17.16 x 17.16 & SM 2008 \\
\hline 12 & MRZ.03 & CR.29 & SM 2008 & 52 & Parc. 17.28 x Parc. 49 & SM 2008 \\
\hline 13 & MRZ.03 & CR.30 & SM 2008 & 53 & Parc. 17.28 x Parc. 49 & SM 2008 \\
\hline 14 & MRZ.03 & CR.31 & SM 2008 & 54 & MRZ.02 X Parc.49 & SM 2008 \\
\hline 15 & MRZ.03 & CR.44 & SM 2008 & 55 & MRZ.02 X Parc.49 & SM 2008 \\
\hline 16 & MRZ.03 & CR.45 & SM 2008 & 56 & MRZ.02 X Parc.49 & SM 2008 \\
\hline 17 & MRZ.03 & CR.46 & SM 2008 & 57 & MRZ.02 X Parc.49 & SM 2008 \\
\hline 18 & MRZ.03 & CR.47 & SM 2008 & 58 & $\mathrm{CH} 01$ & SM 2008 \\
\hline 19 & MRZ.03 & CR.55 & SM 2008 & 59 & $\mathrm{CH} 02$ & SM 2008 \\
\hline 20 & MRZ.03 & CR.56 & SM 2008 & 60 & CH03 & SM 2008 \\
\hline 21 & MRZ.03 & CV.57 & SM 2008 & 61 & ISR. 89-1 & BOT. 2008 \\
\hline 22 & MRZ.03 & CV.58 & SM 2008 & 62 & ISR. 89-2 & BOT. 2008 \\
\hline 23 & MRZ.03 & CV.63 & SM 2008 & 63 & ISR. 89-3 & BOT. 2008 \\
\hline 24 & MRZ.03 & CV.64 & SM 2008 & 64 & SARA P.5 & BOT. 2008 \\
\hline 25 & MRZ.03 & CV.73 & SM 2008 & 65 & SARA P.7 & BOT. 2008 \\
\hline 26 & MRZ.03 & CV.74 & SM 2008 & 66 & SARA P.16 & BOT. 2008 \\
\hline 27 & MRZ.03 & CV.82 & SM 2008 & 67 & SARA P.17 & $\begin{array}{r}\text { BOT. } 2008 \\
\text { (Continua...) }\end{array}$ \\
\hline
\end{tabular}




\begin{tabular}{lllllll}
\hline \multicolumn{2}{l}{. Continuação) } & & & & \\
28 & MRZ.03 & CV.83 & SM 2008 & 68 & SARA P.18 & BOT. 2008 \\
29 & MRZ.03 & CV.87 & SM 2008 & 69 & SARA P.21 & BOT. 2008 \\
30 & MRZ.03 & CV.88 & SM 2008 & 70 & SARA P. 26 & BOT. 2008 \\
31 & MRZ.03 & CV.92 & SM 2008 & 71 & SARA P.28 & BOT. 2008 \\
32 & MRZ.03 & CV.93 & SM 2008 & 72 & SARA P.31 & BOT. 2008 \\
33 & MRZ.03 & CV.95 & SM 2008 & 73 & SARA P.34 & BOT. 2008 \\
34 & MRZ.03 & CV.96 & SM 2008 & 74 & ESTACA 5 P1 & SM 2008 \\
35 & MRZ.03 & CV.97 & SM 2008 & 75 & ESTACA 6 P1 & SM 2008 \\
36 & MRZ.03 & CV.98 & SM 2008 & 76 & ESTACA 7 P1 & SM 2008 \\
37 & MRZ.03 & CV.106 & SM 2008 & 77 & ESTACA 15 P1 & SM 2008 \\
38 & MRZ.03 & CV.107 & SM 2008 & 78 & ESTACA 18 P1 & SM 2008 \\
39 & Ab. MRZ.03 & CV.108 & SM 2008 & 79 & ESTACA 20 P1 & SM 2008 \\
40 & Ab. MRZ.03 & CV.110 & SM 2008 & 80 & ESTACA 20 P2 & SM 2008 \\
\hline
\end{tabular}

\subsubsection{Obtenção das linhagens}

As linhagens foram obtidas por seleção massal para maior porcentagem de florescimento feminino no racemo primário das plantas de mamona. Para tanto, foram realizados ciclos de seleção e autofecundação do racemo primário das plantas selecionadas. As linhagens obtidas pelo Programa de melhoramento genético da FCA (todas com a sigla MRZ) foram selecionadas com seis ciclos de seleção, as linhagens obtidas por estaquia (sigla ESTACA) passaram por cinco ciclos de seleção, os materiais da China por três ciclos de seleção e os materiais de Israel e o híbrido Sara, foram obtidos com dois ciclos de seleção. Os ciclos de seleção foram realizados em condições de safrinha, em dois locais: no município de São Manuel - SP, na Fazenda Experimental São Manuel e no município de Botucatu-SP, na Fazenda Experimental Lageado, ambos pertencentes à Faculdade de Ciências Agronômicas, no Campus de Botucatu - UNESP.

A autofecundação das linhas selecionadas femininas ocorreu quando do início do florescimento, com a proteção da inflorescência nova, com as flores ainda fechadas, com o uso de sacos de papel impermeável. Para evitar a contaminação, os sacos de papel foram retirados somente quando os frutos já estavam desenvolvidos. Os racemos autofecundados foram então marcados com arames coloridos. 


\subsection{Métodos}

\subsubsection{Avaliação das linhagens}

As oitenta linhagens foram avaliadas em dois experimentos, que foram instalados no dia 18 de abril de 2008, no município de Botucatu - SP e no dia 20 de maio de 2008, no município de São Manuel - SP.

Os experimentos foram conduzidos sob delineamento de blocos ao acaso, com duas repetições. As parcelas experimentais constituíram de uma linha com cinco plantas, com espaçamento entre linhas de $1,00 \mathrm{~m}$ e entre plantas de $0,50 \mathrm{~m}$, totalizando 2,0 metros de comprimento e área útil da parcela $2,0 \mathrm{~m}^{2}$.

A semeadura foi realizada manualmente, utilizando três sementes por cova, e aos 35 dias após a semeadura foi realizado o desbaste, deixando uma planta por cova.

Ao longo do ciclo, os tratos culturais, controle de plantas daninhas, adubação de plantio e cobertura foram realizados de acordo com as necessidades da cultura e recomendações descritas por Savy Filho (1997).

A colheita dos experimentos foi realizada em dezembro de 2008, colhendo separadamente os racemos marcados (autofecundados) dos outros racemos (aberto). As sementes dos racemos autofecundados irão compor novas avaliações no ciclo seguinte. Por esse motivo, não foi realizada a avaliação de produtividade de grãos do presente experimento.

\subsubsection{Características avaliadas}

As primeiras avaliações foram realizadas no início do florescimento das plantas, e se basearam na expressão do sexo dos racemos de mamona. Para tanto, visitas ao campo três vezes durante a semana eram realizadas e as observações quanto à expressão feminina ou monóica dos racemos eram anotadas. Esse procedimento foi realizado durante o florescimento de todas as ordens do racemo das linhagens de mamona, sendo que com estes dados foi obtido um histórico completo do florescimento de cada planta. O acompanhamento da expressão do sexo das plantas de mamona foi realizado somente naquelas plantas que 
apresentaram o racemo primário estritamente feminino. A expressão das plantas apresentando o racemo com flores masculinas intercaladas às femininas também foi observado.

Com base nos dados de florescimento obtidos, gerou-se uma tabela com a freqüência de plantas femininas, femininas com flores masculinas intercaladas e plantas monóicas.

Além do histórico do florescimento de cada planta foram avaliadas características de interesse agronômico, quando do desenvolvimento completo das plantas, como:

a) altura média de plantas: foram avaliadas as cinco plantas da parcela, utilizando-se a medida da superfície do solo até o ápice do ramo mais alto, com auxílio de régua graduada, expressos em centímetros.

b) altura de inserção do racemo primário (altura do caule): foram avaliadas cinco plantas da parcela, utilizando-se a medida da superfície do solo até a inserção do primeiro racemo, com auxílio de régua graduada, expressos em centímetros.

c) diâmetro do caule: $\mathrm{O}$ diâmetro caulinar foi determinado na época de maturação dos últimos racemos na base do caule com o auxílio de um paquímetro.

d) número de nós da haste principal até a primeira inflorescência: foram avaliadas cinco plantas da parcela, realizando-se a contagem de número de internódios desde a superfície do solo até a região de inserção do racemo primário.

\subsubsection{Delineamento experimental e análises estatísticas}

Os dados obtidos foram submetidos à análise de variância individual, quadrados médios e respectivas significâncias pelo teste $\mathrm{F}$, segundo o delineamento em blocos ao acaso, utilizando-se o programa SisVar v.4.2 (FERREIRA, 2003). A comparação entre as médias foi realizada pelo teste de Scott-Knott (1974) a 5\% de probabilidade, com o uso do programa SISVAR v.4.2 (FERREIRA, 2003).

Foi realizada a análise conjunta dos dados obtidos no município de São Manuel e Botucatu. As médias das linhagens para as características foram comparadas pelo teste Scott-knott em nível de 5\% de probabilidade. 


\subsection{Dados meteorológicos}

Os dados de temperatura máxima, média e mínima do ar (graus Celsius) e precipitação (mm), para os municípios de Botucatu e São Manuel, para o ciclo da cultura, no período de 01 de abril a 29 de dezembro de 2008 , que foram obtidos do Centro Metereológico da Faculdade de Ciências Agronômicas, UNESP/FCA, estão apresentados nas Figuras 1, 2, 3 e 4.

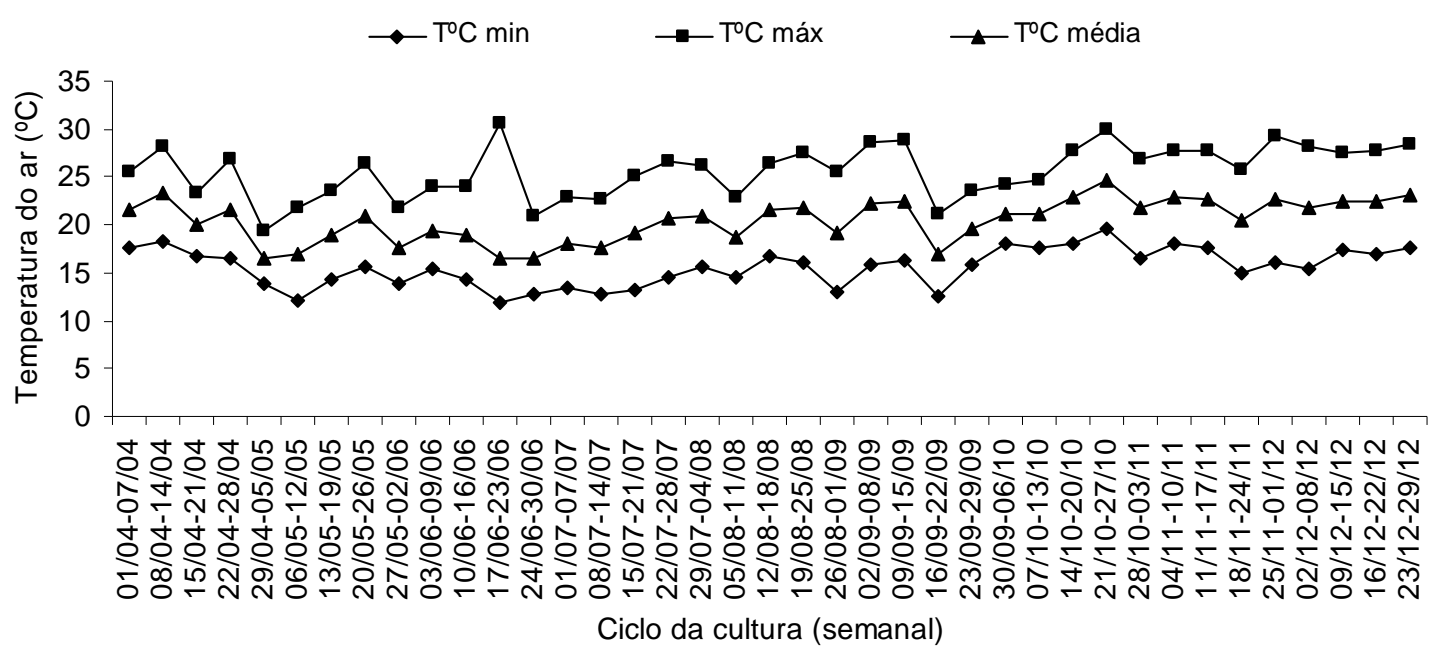

Figura 1. Temperaturas máxima, mínima e média no município de Botucatu, no período de 01 de abril a 29 de dezembro de 2008, referente ao cultivo da safrinha, 2008. 


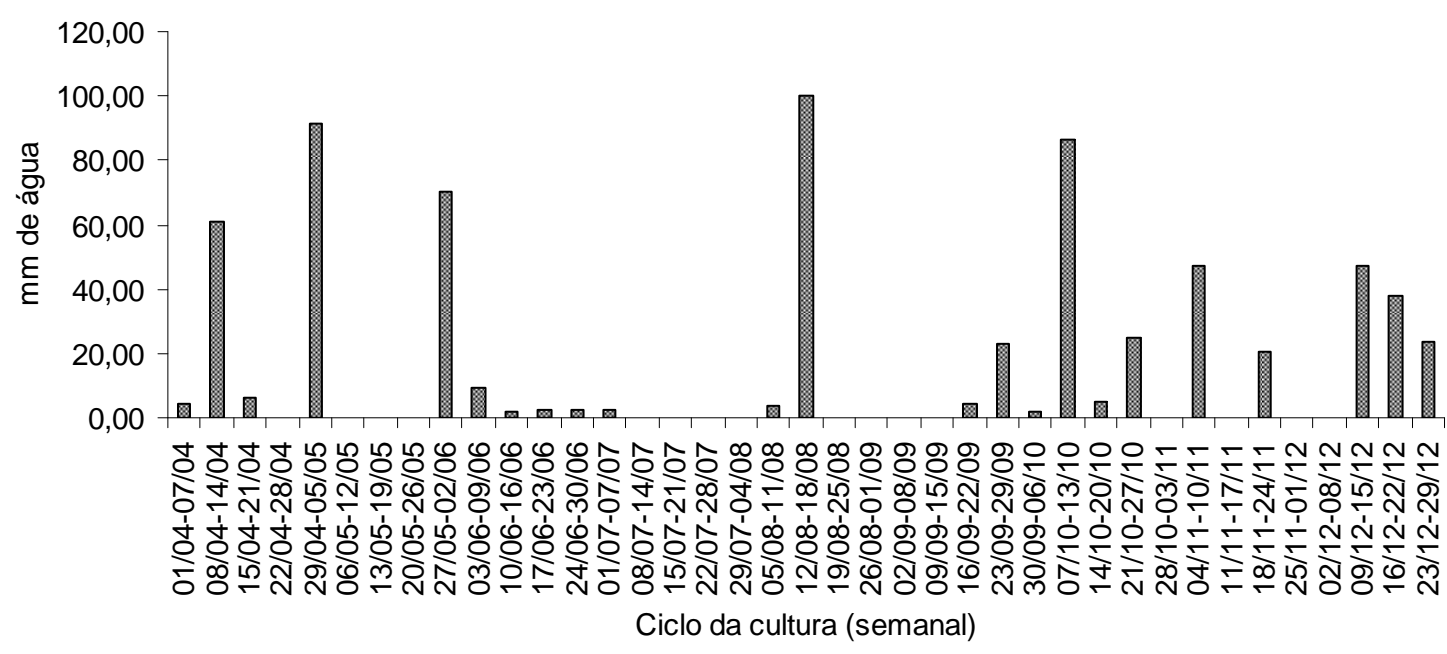

Figura 2. Precipitação em mm no município de Botucatu, no período de 01 de abril a 29 de dezembro de 2008, referente à safrinha de 2008. Freqüência acumulada $679,5 \mathrm{~mm}$.

$\because \mathrm{T}^{\circ} \mathrm{C} \min \quad \because \mathrm{T}^{\circ} \mathrm{C}$ máx $\quad \longrightarrow \mathrm{T}^{\circ} \mathrm{C}$ média

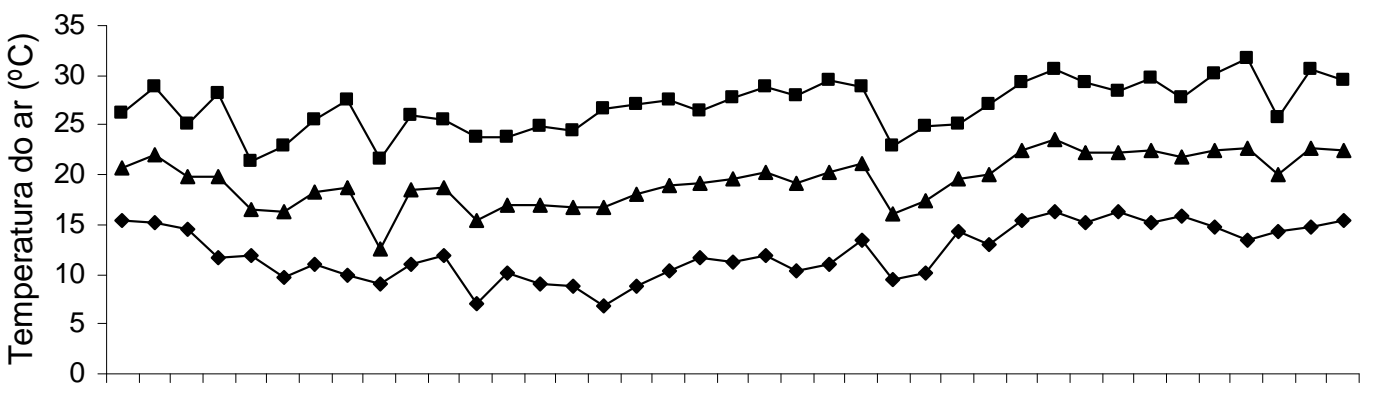

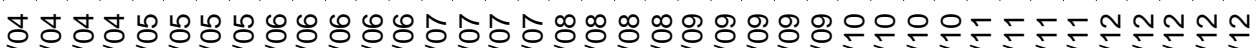

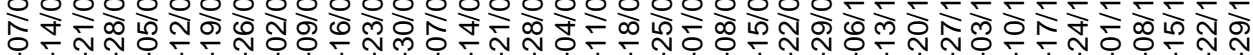

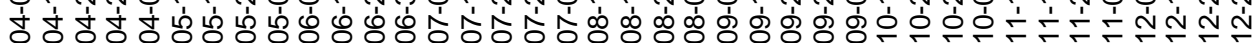

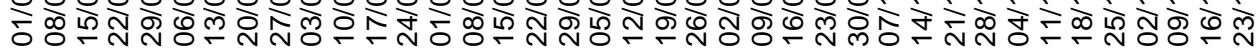
Ciclo da cultura (semanal)

Figura 3. Temperaturas máxima, mínima e média no município de São Manuel, no período de 01 de março a 26 de dezembro de 2008, referente ao cultivo da safrinha 


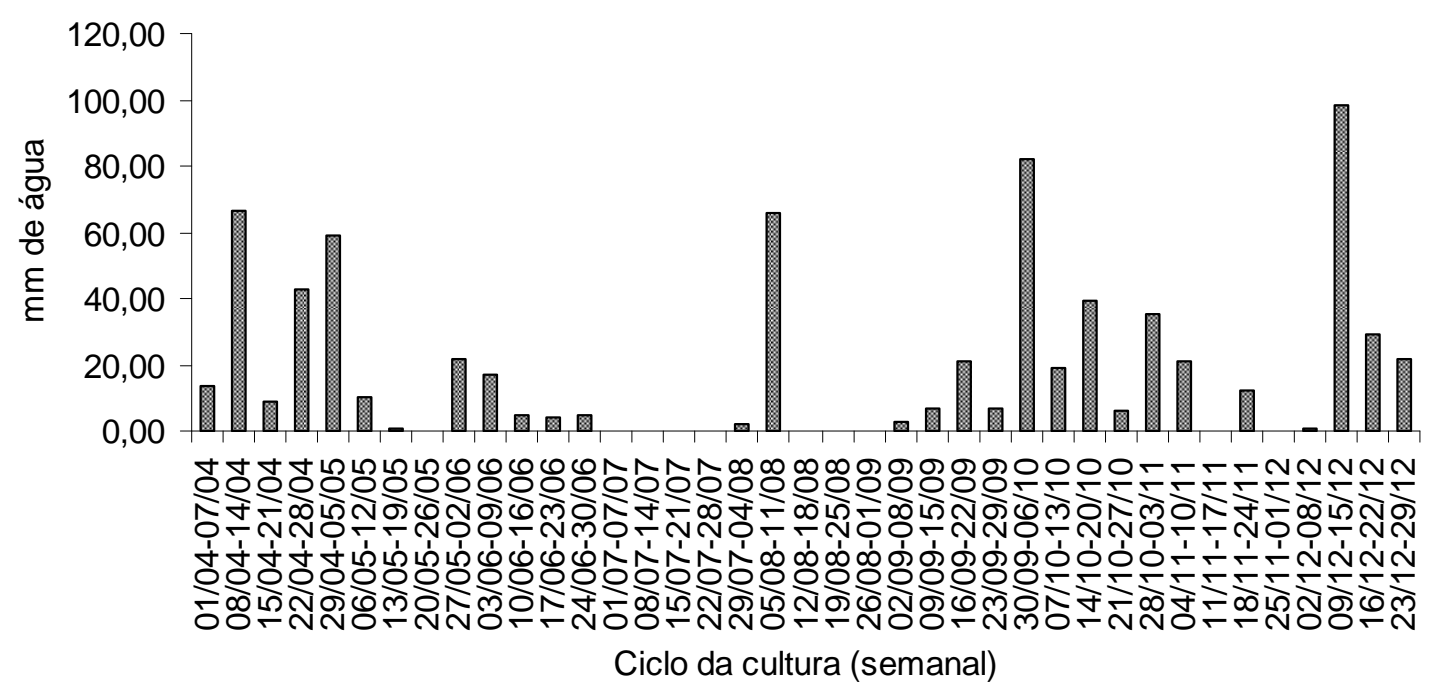

Figura 4. Precipitação em mm no município de São Manuel, no período de 01 de abril a 29 de dezembro de 2008, referente à safrinha de 2008. Freqüência acumulada 724,5 mm. 


\section{RESULTADOS E DISCUSSÃO}

\subsection{Expressão sexual feminina}

O início do florescimento das linhagens de mamona ocorreu em 14/07/2008 (com a semeadura realizada dia 18/04/2008) e o florescimento médio das linhagens foi dia 14/07/2008, para o município de Botucatu-SP. Para o município de São Manuel, o início do florescimento ocorreu dia 30/07, com florescimento médio em 06/08/2008 (a semeadura foi realizada dia 20/05/2008).

$\mathrm{Na}$ Tabela 2 são apresentadas as freqüências de plantas femininas verificadas nas 80 linhagens de mamona, nos municípios de Botucatu-SP e São Manuel-SP, no cultivo de safrinha 2008, avaliadas no período de florescimento das plantas. 
Tabela 2. Frequiências de plantas femininas nas 80 linhagens de mamona, avaliadas nos municípios de Botucatu- SP e São Manuel-SP, na safrinha de 2008.

\begin{tabular}{|c|c|c|c|c|c|}
\hline \multicolumn{6}{|c|}{ Frequência plantas femininas } \\
\hline Linhagens & São Manuel & Botucatu & Linhagens & São Manuel & Botucatu \\
\hline 1 & 100,0 & 100,0 & 41 & 33,3 & 0,0 \\
\hline 2 & 100,0 & 90,0 & 42 & 0,0 & 0,0 \\
\hline 3 & 88,9 & 70,0 & 43 & 0,0 & 0,0 \\
\hline 4 & 100,0 & 90,0 & 44 & 0,0 & 20,0 \\
\hline 5 & 100,0 & 88,9 & 45 & 0,0 & 30,0 \\
\hline 6 & 55,6 & 77,8 & 46 & 0,0 & 20,0 \\
\hline 7 & 88,9 & 66,7 & 47 & 14,3 & 10,0 \\
\hline 8 & 100,0 & 100,0 & 48 & 14,3 & 30,0 \\
\hline 9 & 66,7 & 60,0 & 49 & 0,0 & 0,0 \\
\hline 10 & 100,0 & 100,0 & 50 & 0,0 & 14,3 \\
\hline 11 & 100,0 & 100,0 & 51 & 0,0 & 10,0 \\
\hline 12 & 100,0 & 10,0 & 52 & 0,0 & 0,0 \\
\hline 13 & 0,0 & 0,0 & 53 & 0,0 & 0,0 \\
\hline 14 & 25,0 & 0,0 & 54 & 12,5 & 30,0 \\
\hline 15 & 33,3 & 33,3 & 55 & 75,0 & 22,2 \\
\hline 16 & 11,1 & 100,0 & 56 & 11,1 & 71,4 \\
\hline 17 & 0,0 & 100,0 & 57 & 25,0 & 30,0 \\
\hline 18 & 0,0 & 0,0 & 58 & 0,0 & 0,0 \\
\hline 19 & 50,0 & 88,9 & 59 & 0,0 & 66,7 \\
\hline 20 & 88,9 & 90,0 & 60 & 0,0 & 11,1 \\
\hline 21 & 85,7 & 77,8 & 61 & 0,0 & 20,0 \\
\hline 22 & 80,0 & 88,9 & 62 & 28,6 & 0,0 \\
\hline 23 & 50,0 & 22,2 & 63 & 14,3 & 0,0 \\
\hline 24 & 100,0 & 100,0 & 64 & 0,0 & 0,0 \\
\hline 25 & 100,0 & 100,0 & 65 & 0,0 & 0,0 \\
\hline 26 & 100,0 & 100,0 & 66 & 0,0 & 0,0 \\
\hline 27 & 100,0 & 100,0 & 67 & 0,0 & 10,0 \\
\hline 28 & 90,0 & 100,0 & 68 & 0,0 & 20,0 \\
\hline 29 & 100,0 & 100,0 & 69 & 16,7 & 30,0 \\
\hline 30 & 100,0 & 100,0 & 70 & 0,0 & 0,0 \\
\hline 31 & 0,0 & 100,0 & 71 & 22,2 & 0,0 \\
\hline 32 & 30,0 & 100,0 & 72 & 33,3 & 0,0 \\
\hline 33 & 70,0 & 100,0 & 73 & 83,3 & 0,0 \\
\hline 34 & 60,0 & 90,0 & 74 & 0,0 & 100,0 \\
\hline 35 & 100,0 & 75,0 & 75 & 0,0 & 60,0 \\
\hline 36 & 100,0 & 100,0 & 76 & 25,0 & 0,0 \\
\hline 37 & 70,0 & 77,8 & 77 & 66,7 & 40,0 \\
\hline 38 & 100,0 & 77,8 & 78 & 16,7 & 100,0 \\
\hline 39 & 100,0 & 11,1 & 79 & 0,0 & 40,0 \\
\hline 40 & 100,0 & 0,0 & 80 & 0,0 & 40,0 \\
\hline
\end{tabular}


Observa-se que as linhagens $1,8,10,11,24,25,26,27,29,30$ e 36 apresentaram somente plantas femininas nos dois municípios avaliados. Para determinadas linhagens, o ambiente influenciou a expressão do sexo nas plantas de mamona, como nas linhagens $3,4,7,9,12,14,21,23,35,39,40,41,55,62,63,71,72,73,76$ e 77, onde as condições ambientais do município de São Manuel mostraram-se mais favoráveis a incidência de plantas com racemos femininos. Entretanto, para as linhagens 6, 16, 17, 19, 20, 22, 28, 31, $32,33,34,37,44,45,46,48,50,51,54,56,57,59,60,61,67,68,69,74,75,78,79$ e 80, as condições ambientais do município de Botucatu foram as mais favoráveis. Esses resultados mostram que para a maior parte das linhagens avaliadas, as condições ambientais de BotucatuSP apresentaram-se mais favoráveis à expressão do sexo feminino em plantas de mamona, do que as condições ambientais de São Manuel-SP. Esses resultados diferem de Bertozzo (2009), que obteve maiores porcentagens de florescimento feminino nos racemos primários de plantas de mamona nas condições ambientais do município de São Manuel-SP, em comparação com as condições ambientais de Botucatu-SP, que mostra que o ambiente influencia bastante a expressão sexual e essa influência depende do genótipo com o qual se trabalha.

Nas Figuras 5 e 6 é possível visualizar todas as linhagens que apresentaram plantas monóicas, bem com a freqüência do fenótipo monóico, nos municípios de Botucatu-SP e São Manuel-SP.

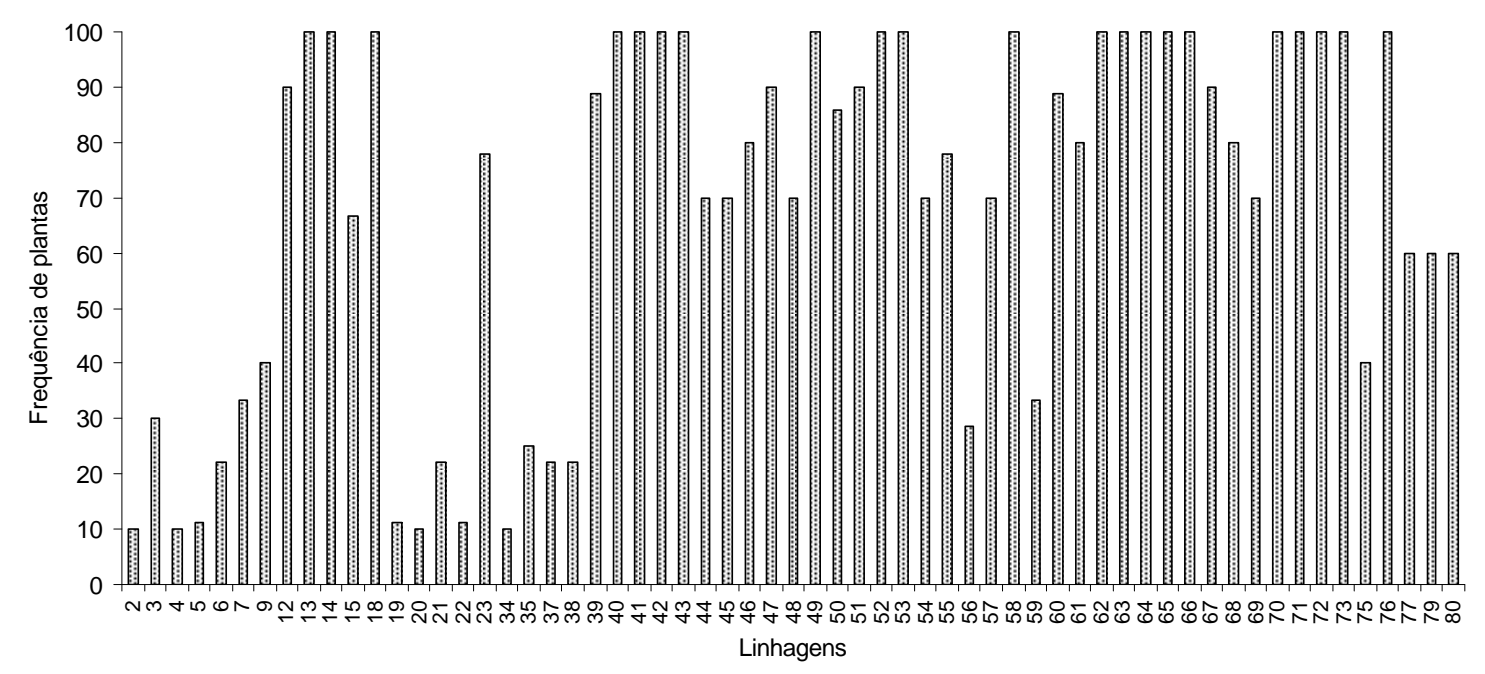

Figura 5. Freqüência de plantas monóicas obtidas nas 80 linhagens de mamona, no município de Botucatu-SP, safrinha 2008. 


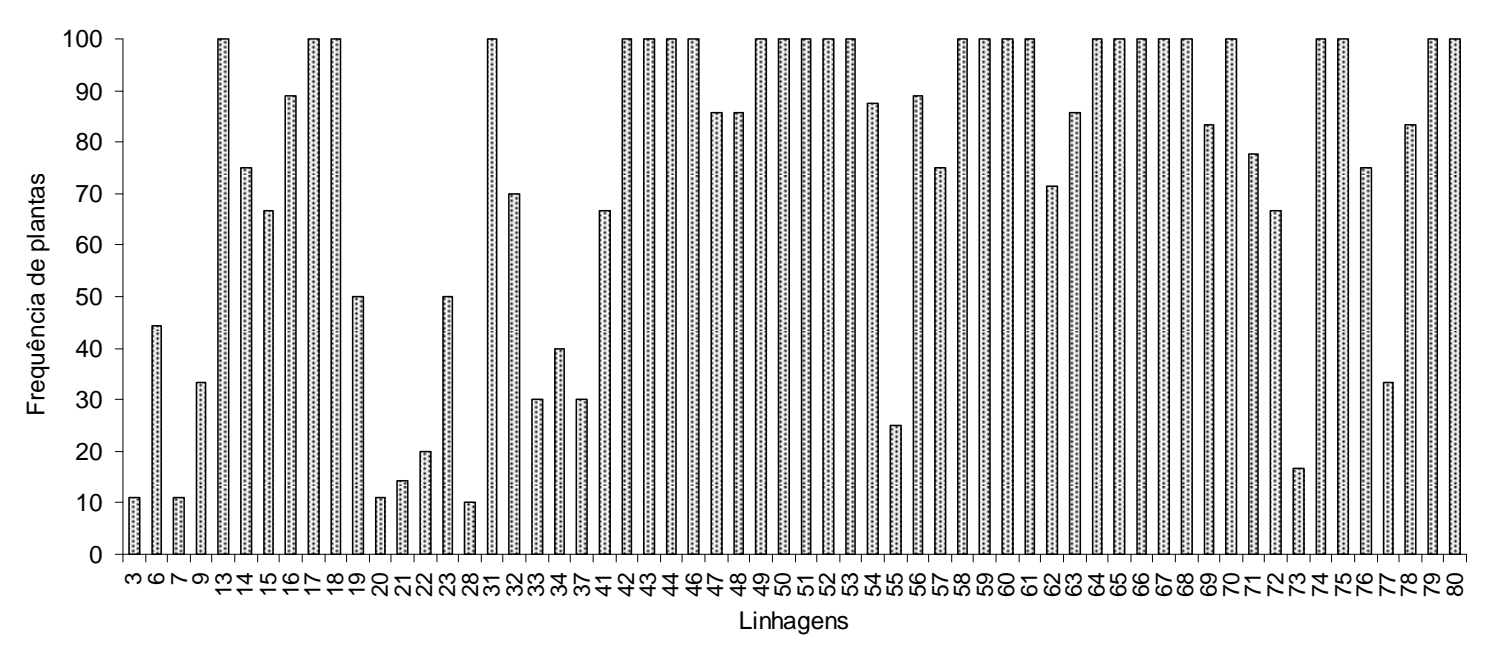

Figura 6. Freqüência de plantas monóicas obtidas nas 80 linhagens de mamona, no município de São Manuel-SP, safrinha 2008.

Com base nas Figuras 5 e 6, é possível verificar as linhagens em que a seleção para a maior porcentagem de florescimento feminino no racemo primário não foi eficiente ou àquelas onde o ambiente influenciou a expressão sexual monóica, a exemplo das linhagens onde todas as plantas se apresentaram como monóicas; e aquelas linhagens em que a pressão de seleção deve ser maior, ou seja, ainda apresentaram plantas monóicas na sua descendência, sendo necessário mais ciclos de seleção e autofecundação para a característica pistilada. Sabe-se que seleção contínua é fundamental para o caráter de feminismo, pois a tendência da planta de mamona é retornar ao monoicismo. Essa seleção deve ser feita principalmente em ambiente que favoreça a tendência masculina, já que é nesse ambiente que facilmente se eliminará aquelas plantas mais instáveis. A seleção será ainda mais eficiente se for baseada no tempo de reversão para o monoicismo.

Além da frequiência de plantas que apresentaram o racemo primário feminino, foi observada ao longo do florescimento, a estabilidade dessas plantas femininas, ou seja, se elas foram femininas estáveis, produzindo somente racemos femininos (PFE), ou se reverteram ao monoicismo ao longo do seu ciclo. A presença de racemos femininos com flores estaminadas intercaladas também foi observada para cada linhagem.

$\mathrm{Na}$ Tabela 3 estão apresentados os totais de plantas femininas da linhagem (PF), aquelas que foram femininas até o final do ciclo (PFE) e dentre as femininas 
àquelas que apresentaram flores estaminadas intercaladas nos racemos femininos (PFEI), para os municípios de Botucatu-SP e São Manuel-SP, respectivamente.

Tabela 3. Total de plantas femininas (PF), plantas femininas estáveis (PFE) e plantas femininas com flores estaminadas intercaladas (PFEI) observadas nas 80 linhagens de mamona, nos municípios de Botucatu-SP e São Manuel-SP, safrinha de 2008.

\begin{tabular}{|c|c|c|c|c|c|c|c|}
\hline \multicolumn{5}{|c|}{ Botucatu-SP } & \multicolumn{3}{|c|}{ São Manuel } \\
\hline Linhagens & PF & PFE & PFEI & Linhagens & PF & PFE & PFEI \\
\hline 1 & 7 & 6 & 1 & 1 & 10 & 2 & 5 \\
\hline 2 & 9 & 4 & 2 & 2 & 9 & 4 & 4 \\
\hline 3 & 7 & 5 & - & 3 & 8 & 4 & 3 \\
\hline 4 & 9 & 4 & 5 & 4 & 9 & 5 & 1 \\
\hline 5 & 8 & 5 & - & 5 & 7 & 4 & 4 \\
\hline 6 & 7 & 4 & 1 & 6 & 5 & - & 1 \\
\hline 7 & 6 & 2 & 1 & 7 & 8 & 5 & 6 \\
\hline 8 & 3 & 3 & - & 8 & 9 & 9 & - \\
\hline 9 & 6 & 2 & 1 & 9 & 6 & 3 & - \\
\hline 10 & 10 & 9 & - & 10 & 10 & 6 & 4 \\
\hline 11 & 9 & 2 & 5 & 11 & 10 & 8 & 8 \\
\hline 12 & 4 & 3 & - & 12 & 8 & 8 & 1 \\
\hline 15 & 3 & 1 & - & 14 & 2 & 2 & 2 \\
\hline 16 & 8 & 7 & - & 15 & 3 & 2 & - \\
\hline 17 & 8 & 8 & 3 & 16 & 1 & - & - \\
\hline 19 & 8 & 6 & 3 & 19 & 3 & 3 & 3 \\
\hline 20 & 9 & 5 & 4 & 20 & 8 & 4 & 7 \\
\hline 21 & 7 & 2 & 4 & 21 & 6 & 3 & 3 \\
\hline 22 & 8 & 2 & - & 22 & 8 & 5 & 5 \\
\hline 23 & 2 & 2 & - & 23 & 5 & 4 & - \\
\hline 24 & 6 & 5 & 2 & 24 & 7 & 3 & 4 \\
\hline 25 & 10 & 9 & 3 & 25 & 7 & 3 & 5 \\
\hline 26 & 10 & 9 & 5 & 26 & 10 & 5 & 7 \\
\hline 27 & 10 & 8 & 3 & 27 & 10 & 3 & 9 \\
\hline 28 & 10 & 5 & 6 & 28 & 9 & 5 & 8 \\
\hline 29 & 10 & 7 & 5 & 29 & 10 & 2 & 8 \\
\hline 30 & 10 & 8 & 4 & 30 & 9 & 6 & 7 \\
\hline 31 & 10 & 9 & 3 & 32 & 3 & 2 & - \\
\hline 32 & 10 & 7 & 3 & 33 & 7 & 2 & 4 \\
\hline 33 & 9 & 4 & - & 34 & 6 & 2 & 6 \\
\hline 34 & 9 & 4 & 2 & 35 & 8 & 9 & 7 \\
\hline 35 & 6 & 5 & 2 & 36 & 8 & 5 & 3 \\
\hline 36 & 10 & 9 & 1 & 37 & 7 & 5 & 3 \\
\hline 37 & 7 & 2 & - & 38 & 9 & 7 & $\begin{array}{c}3 \\
\text { Continua...) }\end{array}$ \\
\hline
\end{tabular}




\begin{tabular}{cccccccc}
\hline (..Continuação) & & & & & & \\
$\mathbf{3 8}$ & 7 & 6 & - & $\mathbf{3 9}$ & 8 & 8 & 3 \\
$\mathbf{3 9}$ & 1 & 0 & - & $\mathbf{4 0}$ & 9 & 9 & - \\
$\mathbf{4 4}$ & 2 & 1 & - & $\mathbf{4 1}$ & 2 & 2 & - \\
$\mathbf{4 5}$ & 3 & 3 & - & $\mathbf{4 7}$ & 1 & - & - \\
$\mathbf{4 6}$ & 2 & 1 & - & $\mathbf{4 8}$ & 1 & - & - \\
$\mathbf{4 7}$ & 1 & - & - & $\mathbf{5 4}$ & 1 & - & - \\
$\mathbf{4 8}$ & 3 & 2 & - & $\mathbf{5 5}$ & 6 & 2 & - \\
$\mathbf{5 0}$ & 1 & - & - & $\mathbf{5 6}$ & 1 & 1 & - \\
$\mathbf{5 1}$ & 1 & 1 & - & $\mathbf{5 7}$ & 2 & 2 & - \\
$\mathbf{5 4}$ & 3 & 3 & - & $\mathbf{6 2}$ & 2 & - & - \\
$\mathbf{5 5}$ & 2 & 2 & - & $\mathbf{6 3}$ & 1 & - & - \\
$\mathbf{5 6}$ & 5 & 4 & - & $\mathbf{6 9}$ & 1 & - & - \\
$\mathbf{5 7}$ & 3 & 3 & - & $\mathbf{7 1}$ & 2 & 1 & - \\
$\mathbf{5 9}$ & 4 & 1 & - & $\mathbf{7 2}$ & 3 & - & - \\
$\mathbf{6 0}$ & 1 & 1 & - & $\mathbf{7 3}$ & 5 & 4 & - \\
$\mathbf{6 1}$ & 2 & - & - & $\mathbf{7 6}$ & 1 & - & - \\
$\mathbf{6 7}$ & 1 & 1 & - & $\mathbf{7 7}$ & 6 & 3 & - \\
$\mathbf{6 8}$ & 2 & 2 & - & $\mathbf{7 8}$ & 1 & 1 & \\
$\mathbf{6 9}$ & 3 & 3 & - & & & & \\
$\mathbf{7 4}$ & 10 & 9 & 1 & & & & \\
$\mathbf{7 5}$ & 3 & - & - & & & & \\
$\mathbf{7 7}$ & 4 & 3 & - & & & & \\
$\mathbf{7 8}$ & 10 & 6 & 2 & & & & \\
$\mathbf{7 9}$ & 4 & - & - & & & & \\
$\mathbf{8 0}$ & 4 & - & 3 & & & & \\
\hline
\end{tabular}

Com base nos dados da tabela acima, é verificado que o município de Botucatu-SP apresentou 65,7 \% de plantas femininas estáveis, enquanto que o município de São Manuel-SP obteve 58,1\%. As condições ambientais do município de Botucatu mostraramse mais uma vez favoráveis à expressão do sexo feminino, já que essas linhagens produziram somente racemos femininos ao longo de sua ontogenia. Para fins de melhoramento e também para a produção de linhas híbridas de mamona, esses resultados são de extrema importância. Com base nesse resultado, a condução de campos de produção de mamona nas condições ambientais de Botucatu pode apresentar ganhos expressivos; tanto em termos de aumento de produtividade na área semeado (já que os racemos produzem mais frutos e grãos), quanto em termos de condução de campos para produção de híbridos, onde a linhagem de mamona expressa a característica de feminilidade favoravelmente. Plantas de mamona femininas geneticamente estáveis são relatadas por diversos autores, a exemplo de Claassen e Hoffman 
(1949), Shifriss, (1956) e Popova e Moshkin (1986). Um exemplo encontrado na literatura é a linha fêmea Nebraska 145-4, relatada por Shifriss em 1956, contudo, tais plantas são consideradas raras na natureza. A raridade dessas plantas ocorre em virtude do fenótipo de reversão sexual mostrar-se como "dominante" sobre o fenótipo de linhas estáveis (SHIFRISS, 1960).

Para os valores de plantas femininas com flores estaminadas intercaladas, as condições ambientais do município de Botucatu-SP apresentaram 21,6\% de plantas com tal fenótipo, enquanto que para as condições ambientais do município de São Manuel-SP, a frequência foi de 45,9\%. Fatores ambientais como altas temperaturas e deficiência hídrica são relatados como determinantes para a produção de racemos femininos com flores masculinas intercaladas; entretanto, como pode ser verificado pelas médias de temperatura nos município de Botucatu $\left(20,45^{\circ} \mathrm{C}\right)$ e São Manuel $\left(19,47^{\circ} \mathrm{C}\right)$ e precipitação total para o município de Botucatu $(679,5 \mathrm{~mm})$ e São Manuel $(724,5 \mathrm{~mm})$ durante o desenvolvimento completo das plantas de mamona, não houve diferenças significativas das variáveis ambientais nos municípios em questão. Por isso, são necessários mais estudos para se avaliar qual o fator ambiental mais influente. A alta freqüência de plantas com esse fenótipo em São Manuel-SP é de grande interesse para a produção de linhas híbridas de mamona, com o uso dos genes "ambientalmente sensíveis" relatados primeiramente por Zimmerman e Smith (1966). O uso desses genes para a produção de híbridos de mamona reduz os custos com o "rouguing" de plantas monóicas, que eram usadas como fornecedoras de pólen, na proporção de 20-25\%. Na Índia, a produção de híbridos já vem sendo realizada com o uso de plantas que apresentam o fenótipo intercalado. Com base nos resultados obtidos, as condições ambientais do município de São Manuel podem ser consideradas aptas para implantação de campos de produção de sementes híbridas de mamona.

De um total de 80 linhagens de mamona avaliadas quanto à expressão sexual, em dois ambientes, foi verificado que 11 linhagens apresentaram-se como femininas (estáveis ou não) e 12 linhagens apresentaram-se como monóicas. 


\subsection{Altura de planta, altura de inserção do racemo primário, diâmetro de caule e número de nós até a inflorescência primária}

Além da expressão sexual das linhagens de mamona, foram avaliadas as características altura de planta, altura de inserção do racemo primário, diâmetro de caule e número de nós até a inflorescência primária. Essas características são de grande importância para o cultivo de mamona com colheita mecanizada, e devem também ser levadas em consideração na seleção de plantas. Outro importante ponto é avaliar se a seleção de plantas femininas de mamona interfere nessas características.

Os quadrados médios das análises individuais obtidos nas 80 linhagens de mamona do programa de melhoramento FCA-UNESP, avaliados na safrinha de 2008 nos municípios de Botucatu - SP e São Manuel - SP para as características altura de planta (AP), altura de inserção do racemo primário (AI), diâmetro de caule (DC) e número de nós da haste principal até a primeira inflorescência $(\mathrm{NN})$, a respectiva significância, médias gerais e coeficientes de variação experimental são apresentados nas Tabelas 4 e 5.

Tabela 4. Quadrados médios obtidos das análises de variâncias para as características altura de planta (AP), altura de inserção do racemo primário (AI), diâmetro de caule (DC) e número de nós da haste principal até a primeira inflorescência $(\mathrm{NN})$, avaliados em linhagens de mamona, no município de Botucatu-SP, safrinha de 2008.

\begin{tabular}{cccccc}
\hline F.V. & G.L. & AP $(\mathrm{cm})$ & AI $(\mathrm{cm})$ & DC $(\mathrm{cm})$ & NN \\
\hline Bloco & 1 & 8456,38 & 25,64 & 1,746 & 4,57 \\
Tratamento & 78 & $377,30^{* *}$ & $74,36^{* *}$ & $0,155^{* *}$ & $10,01^{* *}$ \\
Erro & 78 & 165,25 & 27,80 & 0,788 & 2,08 \\
\hline Média & & 62,15 & 28,88 & 1,549 & 10,15 \\
CV $(\%)$ & & 20,68 & 18,26 & 18,13 & 14,23 \\
\hline
\end{tabular}

** significativo $\mathrm{e}^{\text {ns }}$ não significativo, a $5 \%$ de probabilidade pelo teste $\mathrm{F}$.

No município de Botucatu-SP, verifica-se que as linhagens diferiram entre si, ao nível de 5\% de probabilidade, pelo teste $\mathrm{F}$, para as características altura de planta, altura de inserção do racemo primário, diâmetro de caule e número de nós da haste principal até a primeira inflorescência, demonstrando a variabilidade genética existente na mamoneira para todas as características. 
Tabela 5. Quadrados médios obtidos das análises de variâncias para as características altura de planta (AP), altura de inserção do racemo primário (AI), diâmetro de caule (DC) e número de nós da haste principal até a primeira inflorescência $(\mathrm{NN})$, avaliados em linhagens de mamona, no município de São Manuel-SP, safrinha de 2008.

\begin{tabular}{cccccc}
\hline F.V. & G.L. & AP $(\mathrm{cm})$ & AI $(\mathrm{cm})$ & DC $(\mathrm{cm})$ & NN \\
\hline Bloco & 1 & 35,61 & 9,70 & 0,781 & 0,26 \\
Tratamento & 78 & $938,12^{* *}$ & $193,54^{* *}$ & $0,535^{* *}$ & $5,92^{* *}$ \\
Erro & 78 & 394,12 & 34,04 & 0,270 & 0,76 \\
\hline Média & & 120,56 & 33,90 & 2,61 & 10,95 \\
CV $(\%)$ & & 16,47 & 17,21 & 19,88 & 7,98 \\
\hline
\end{tabular}

** significativo e ${ }^{\text {ns }}$ não significativo, a $5 \%$ de probabilidade pelo teste $\mathrm{F}$.

Para o experimento no município de São Manuel-SP, os quadrados médios de todas as características avaliadas foram significativos ao nível de 5\%, pelo teste $\mathrm{F}$, mostrando que as linhagens diferem geneticamente para essas características, apresentando grande variabilidade.

Nas Tabelas 6 e 7, são apresentadas as médias gerais para as características altura de plantas (AP), altura de inserção do racemo primário (AI), diâmetro de caule (DC) e número de nós da haste principal até a primeira inflorescência $(\mathrm{NN})$, avaliadas em linhagens de mamona, nos municípios de Botucatu-SP e São Manuel-SP, safrinha de 2008.

Tabela 6. Médias gerais para as características altura de plantas (AP), altura de inserção do racemo primário (AI), diâmetro de caule (DC) e número de nós da haste principal até a primeira inflorescência (NN), avaliadas em linhagens de mamona, experimento em Botucatu-SP, safrinha de 2008.

\begin{tabular}{cccccccc}
\hline Linhagens & $\begin{array}{c}\text { AP } \\
(\mathbf{c m})\end{array}$ & Linhagens & $\begin{array}{c}\text { AI } \\
(\mathbf{c m})\end{array}$ & Linhagens & $\begin{array}{c}\text { DC } \\
(\mathbf{c m})\end{array}$ & Linhagens & NN \\
\hline $\mathbf{3 7}$ & $35,5 \mathrm{a}$ & $\mathbf{7 6}$ & $15,5 \mathrm{a}$ & $\mathbf{3 7}$ & $0,90 \mathrm{a}$ & $\mathbf{6 2}$ & $5,5 \mathrm{a}$ \\
$\mathbf{3 8}$ & $38,0 \mathrm{a}$ & $\mathbf{5 0}$ & $18,5 \mathrm{a}$ & $\mathbf{3 8}$ & $1,05 \mathrm{a}$ & $\mathbf{5 5}$ & $6,5 \mathrm{a}$ \\
$\mathbf{7 0}$ & $40,0 \mathrm{a}$ & $\mathbf{7 5}$ & $18,5 \mathrm{a}$ & $\mathbf{6 6}$ & $1,15 \mathrm{a}$ & $\mathbf{6 1}$ & $6,5 \mathrm{a}$ \\
$\mathbf{7 6}$ & $42,0 \mathrm{a}$ & $\mathbf{3 8}$ & $19,0 \mathrm{a}$ & $\mathbf{3 6}$ & $1,20 \mathrm{a}$ & $\mathbf{4 4}$ & $7,0 \mathrm{a}$ \\
$\mathbf{3 4}$ & $42,0 \mathrm{a}$ & $\mathbf{4 9}$ & $19,5 \mathrm{a}$ & $\mathbf{6 1}$ & $1,20 \mathrm{a}$ & $\mathbf{5}$ & $7,0 \mathrm{a}$ \\
$\mathbf{3 2}$ & $43,0 \mathrm{a}$ & $\mathbf{1}$ & $21,0 \mathrm{a}$ & $\mathbf{7 0}$ & $1,25 \mathrm{a}$ & $\mathbf{1 0}$ & $7,5 \mathrm{a}$ \\
$\mathbf{6 8}$ & $44,0 \mathrm{a}$ & $\mathbf{5}$ & $21,0 \mathrm{a}$ & $\mathbf{3 4}$ & $1,25 \mathrm{a}$ & $\mathbf{4 6}$ & $7,5 \mathrm{a}$ \\
$\mathbf{6 6}$ & $45,5 \mathrm{a}$ & $\mathbf{7 0}$ & $21,0 \mathrm{a}$ & $\mathbf{6 3}$ & $1,25 \mathrm{a}$ & $\mathbf{5 7}$ & $7,5 \mathrm{a}$ \\
$\mathbf{1 6}$ & $47,5 \mathrm{a}$ & $\mathbf{8 0}$ & $21,5 \mathrm{a}$ & $\mathbf{4 0}$ & $1,25 \mathrm{a}$ & $\mathbf{9}$ & $7,5 \mathrm{a}$ \\
$\mathbf{4 0}$ & $47,5 \mathrm{a}$ & $\mathbf{3 7}$ & $21,5 \mathrm{a}$ & $\mathbf{6 2}$ & $1,25 \mathrm{a}$ & $\mathbf{1}$ & $7,5 \mathrm{a}$ \\
$\mathbf{3 3}$ & $47,5 \mathrm{a}$ & $\mathbf{4 6}$ & $22,0 \mathrm{a}$ & $\mathbf{2 5}$ & $1,30 \mathrm{a}$ & $\mathbf{5 0}$ & $7,5 \mathrm{a}$ \\
& & & & & & & (Continua..$)$ \\
\hline
\end{tabular}




\begin{tabular}{|c|c|c|c|c|c|c|c|}
\hline \multicolumn{8}{|c|}{ (...Continuação) } \\
\hline 75 & $48,0 \mathrm{a}$ & 65 & $23,0 \mathrm{a}$ & 68 & $1,30 \mathrm{a}$ & 80 & $8,0 \mathrm{a}$ \\
\hline 36 & $48,0 \mathrm{a}$ & 44 & $23,0 \mathrm{a}$ & 16 & $1,30 \mathrm{a}$ & 70 & $8,0 \mathrm{a}$ \\
\hline 5 & $48,5 \mathrm{a}$ & 48 & $23,0 \mathrm{a}$ & 26 & $1,30 \mathrm{a}$ & 21 & $8,0 \mathrm{a}$ \\
\hline 26 & $49,0 \mathrm{a}$ & 3 & $23,0 \mathrm{a}$ & 17 & $1,35 \mathrm{a}$ & 63 & $8,0 \mathrm{a}$ \\
\hline 25 & $49,5 \mathrm{a}$ & 79 & $23,5 \mathrm{a}$ & 76 & $1,35 \mathrm{a}$ & 76 & $8,0 \mathrm{a}$ \\
\hline 1 & $50,5 \mathrm{a}$ & 52 & $23,5 \mathrm{a}$ & 69 & $1,35 \mathrm{a}$ & 48 & $8,0 \mathrm{a}$ \\
\hline 31 & $51,0 \mathrm{a}$ & 68 & $24,5 \mathrm{a}$ & 65 & $1,35 \mathrm{a}$ & 47 & $8,5 \mathrm{a}$ \\
\hline 69 & $51,5 \mathrm{a}$ & 16 & $25,0 \mathrm{a}$ & 60 & $1,40 \mathrm{a}$ & 38 & $8,5 \mathrm{a}$ \\
\hline 44 & $51,5 \mathrm{a}$ & 36 & $25,0 \mathrm{a}$ & 18 & $1,40 \mathrm{a}$ & 49 & $8,5 \mathrm{a}$ \\
\hline 39 & $52,5 \mathrm{a}$ & 9 & $25,0 \mathrm{a}$ & 14 & $1,40 \mathrm{a}$ & 54 & $8,5 \mathrm{a}$ \\
\hline 48 & $53,0 \mathrm{a}$ & 31 & $25,5 \mathrm{a}$ & 6 & $1,40 \mathrm{a}$ & 79 & $8,5 \mathrm{a}$ \\
\hline 3 & $53,5 \mathrm{a}$ & 71 & $25,5 \mathrm{a}$ & 44 & $1,40 \mathrm{a}$ & 29 & $8,5 \mathrm{a}$ \\
\hline 6 & $54,0 \mathrm{a}$ & 66 & $25,5 \mathrm{a}$ & 31 & $1,40 \mathrm{a}$ & 56 & $9,0 \mathrm{a}$ \\
\hline 35 & $54,0 \mathrm{a}$ & 21 & $25,5 \mathrm{a}$ & 32 & $1,40 \mathrm{a}$ & 53 & $9,0 \mathrm{a}$ \\
\hline 46 & $54,5 \mathrm{a}$ & 34 & $25,5 \mathrm{a}$ & 33 & $1,40 \mathrm{a}$ & 39 & $9,0 \mathrm{a}$ \\
\hline 24 & $54,5 \mathrm{a}$ & 53 & $25,5 \mathrm{a}$ & 71 & $1,40 \mathrm{a}$ & 26 & $9,0 \mathrm{a}$ \\
\hline 74 & $55,0 \mathrm{a}$ & 51 & $26,5 \mathrm{a}$ & 19 & $1,40 \mathrm{a}$ & 14 & $9,0 \mathrm{a}$ \\
\hline 65 & $55,5 \mathrm{a}$ & 29 & $26,5 \mathrm{a}$ & 24 & $1,40 \mathrm{a}$ & 22 & $9,5 \mathrm{a}$ \\
\hline 22 & $56,5 \mathrm{a}$ & 25 & $26,5 \mathrm{a}$ & 1 & $1,40 \mathrm{a}$ & 17 & $9,5 \mathrm{a}$ \\
\hline 71 & $57,0 \mathrm{a}$ & 47 & $27,0 \mathrm{a}$ & 35 & $1,45 \mathrm{~b}$ & 20 & $9,5 \mathrm{a}$ \\
\hline 61 & $57,5 \mathrm{a}$ & 6 & $27,0 \mathrm{a}$ & 73 & $1,45 \mathrm{~b}$ & 13 & $9,5 \mathrm{a}$ \\
\hline 73 & $58,0 \mathrm{a}$ & 26 & $27,5 \mathrm{a}$ & 20 & $1,45 \mathrm{~b}$ & 3 & $9,5 \mathrm{a}$ \\
\hline 27 & $58,5 \mathrm{a}$ & 7 & $27,5 \mathrm{a}$ & 39 & $1,45 \mathrm{~b}$ & 52 & $9,5 \mathrm{a}$ \\
\hline 49 & $58,5 \mathrm{a}$ & 14 & $28,0 \mathrm{a}$ & 75 & $1,50 \mathrm{~b}$ & 11 & $9,5 \mathrm{a}$ \\
\hline 29 & $58,5 \mathrm{a}$ & 19 & $28,0 \mathrm{a}$ & 3 & $1,50 \mathrm{~b}$ & 6 & $9,5 \mathrm{a}$ \\
\hline 51 & $59,0 \mathrm{a}$ & 4 & $28,0 \mathrm{a}$ & 72 & $1,50 \mathrm{~b}$ & 32 & $9,5 \mathrm{a}$ \\
\hline 19 & $60,0 \mathrm{a}$ & 41 & $28,5 \mathrm{a}$ & 46 & $1,50 \mathrm{~b}$ & 34 & $9,5 \mathrm{a}$ \\
\hline 9 & $60,5 \mathrm{a}$ & 78 & $28,5 \mathrm{a}$ & 27 & $1,50 \mathrm{~b}$ & 31 & $9,5 \mathrm{a}$ \\
\hline 72 & $61,0 \mathrm{a}$ & 33 & $28,5 \mathrm{a}$ & 29 & $1,50 \mathrm{~b}$ & 30 & $10,0 \mathrm{a}$ \\
\hline 30 & $61,0 \mathrm{a}$ & 69 & $28,5 \mathrm{a}$ & 30 & $1,50 \mathrm{~b}$ & 25 & $10,0 \mathrm{a}$ \\
\hline 17 & $62,0 \mathrm{a}$ & 20 & $28,5 \mathrm{a}$ & 11 & $1,50 \mathrm{~b}$ & 36 & $10,0 \mathrm{a}$ \\
\hline 62 & $63,0 \mathrm{a}$ & 35 & $28,5 \mathrm{a}$ & 15 & $1,50 \mathrm{~b}$ & 37 & $10,0 \mathrm{a}$ \\
\hline 7 & $63,0 \mathrm{a}$ & 22 & $29,0 \mathrm{a}$ & 22 & $1,50 \mathrm{~b}$ & 18 & $10,0 \mathrm{a}$ \\
\hline 21 & $64,0 \mathrm{~b}$ & 11 & $29,0 \mathrm{a}$ & 10 & $1,50 \mathrm{~b}$ & 4 & $10,5 \mathrm{a}$ \\
\hline 50 & $64,0 \mathrm{~b}$ & 43 & $29,0 \mathrm{a}$ & 9 & $1,50 \mathrm{~b}$ & 27 & $10,5 \mathrm{a}$ \\
\hline 20 & $64,5 \mathrm{~b}$ & 40 & $29,5 \mathrm{a}$ & 5 & $1,55 \mathrm{~b}$ & 28 & $10,5 \mathrm{a}$ \\
\hline 28 & $65,0 \mathrm{~b}$ & 18 & $29,5 \mathrm{a}$ & 59 & $1,55 \mathrm{~b}$ & 35 & $10,5 \mathrm{a}$ \\
\hline 63 & $65,0 \mathrm{~b}$ & 32 & $30,0 \mathrm{a}$ & 28 & $1,55 \mathrm{~b}$ & 75 & $10,5 \mathrm{a}$ \\
\hline 47 & $65,5 \mathrm{~b}$ & 17 & $30,5 \mathrm{~b}$ & 74 & $1,60 \mathrm{~b}$ & 78 & $10,5 \mathrm{a}$ \\
\hline 10 & $66,0 \mathrm{~b}$ & 42 & $30,5 \mathrm{~b}$ & 7 & $1,60 \mathrm{~b}$ & 24 & $10,5 \mathrm{a}$ \\
\hline 4 & $66,0 \mathrm{~b}$ & 10 & $31,0 \mathrm{~b}$ & 48 & $1,60 \mathrm{~b}$ & 15 & $11,0 \mathrm{~b}$ \\
\hline 53 & $66,5 \mathrm{~b}$ & 2 & $31,0 \mathrm{~b}$ & 13 & $1,65 \mathrm{~b}$ & 40 & $11,0 \mathrm{~b}$ \\
\hline 14 & $67,0 \mathrm{~b}$ & 27 & $31,5 \mathrm{~b}$ & 77 & $1,65 \mathrm{~b}$ & 12 & $\begin{array}{c}11,0 \mathrm{~b} \\
\text { (Continua...) }\end{array}$ \\
\hline
\end{tabular}




\begin{tabular}{cccccccc}
\hline \multicolumn{2}{c}{ (..Continuação) } & & & & & & \\
$\mathbf{2}$ & $68,0 \mathrm{~b}$ & $\mathbf{2 8}$ & $31,5 \mathrm{~b}$ & $\mathbf{2 1}$ & $1,65 \mathrm{~b}$ & $\mathbf{5 1}$ & $11,0 \mathrm{~b}$ \\
$\mathbf{1 1}$ & $68,0 \mathrm{~b}$ & $\mathbf{6 7}$ & $32,0 \mathrm{~b}$ & $\mathbf{4 9}$ & $1,65 \mathrm{~b}$ & $\mathbf{4 3}$ & $11,0 \mathrm{~b}$ \\
$\mathbf{7 9}$ & $68,0 \mathrm{~b}$ & $\mathbf{2 4}$ & $32,0 \mathrm{~b}$ & $\mathbf{2}$ & $1,70 \mathrm{~b}$ & $\mathbf{6 5}$ & $11,5 \mathrm{~b}$ \\
$\mathbf{1 5}$ & $69,0 \mathrm{~b}$ & $\mathbf{3 0}$ & $32,5 \mathrm{~b}$ & $\mathbf{5 0}$ & $1,70 \mathrm{~b}$ & $\mathbf{1 9}$ & $11,5 \mathrm{~b}$ \\
$\mathbf{7 8}$ & $69,5 \mathrm{~b}$ & $\mathbf{7 7}$ & $32,5 \mathrm{~b}$ & $\mathbf{7 9}$ & $1,70 \mathrm{~b}$ & $\mathbf{6 8}$ & $11,5 \mathrm{~b}$ \\
$\mathbf{8}$ & $69,5 \mathrm{~b}$ & $\mathbf{1 5}$ & $32,5 \mathrm{~b}$ & $\mathbf{1 2}$ & $1,70 \mathrm{~b}$ & $\mathbf{6 6}$ & $11,5 \mathrm{~b}$ \\
$\mathbf{4 1}$ & $71,0 \mathrm{~b}$ & $\mathbf{6 3}$ & $33,0 \mathrm{~b}$ & $\mathbf{6 7}$ & $1,70 \mathrm{~b}$ & $\mathbf{7 1}$ & $12,0 \mathrm{~b}$ \\
$\mathbf{1 8}$ & $71,0 \mathrm{~b}$ & $\mathbf{7 3}$ & $33,5 \mathrm{~b}$ & $\mathbf{8}$ & $1,70 \mathrm{~b}$ & $\mathbf{6 7}$ & $12,0 \mathrm{~b}$ \\
$\mathbf{6 0}$ & $71,0 \mathrm{~b}$ & $\mathbf{7 2}$ & $33,5 \mathrm{~b}$ & $\mathbf{5 3}$ & $1,75 \mathrm{~b}$ & $\mathbf{7}$ & $12,0 \mathrm{~b}$ \\
$\mathbf{5 2}$ & $71,0 \mathrm{~b}$ & $\mathbf{1 2}$ & $34,0 \mathrm{~b}$ & $\mathbf{5 2}$ & $1,75 \mathrm{~b}$ & $\mathbf{4 2}$ & $12,0 \mathrm{~b}$ \\
$\mathbf{7 7}$ & $71,5 \mathrm{~b}$ & $\mathbf{3 9}$ & $34,0 \mathrm{~b}$ & $\mathbf{4 7}$ & $1,75 \mathrm{~b}$ & $\mathbf{3 3}$ & $12,0 \mathrm{~b}$ \\
$\mathbf{6 7}$ & $72,0 \mathrm{~b}$ & $\mathbf{6 4}$ & $34,0 \mathrm{~b}$ & $\mathbf{4}$ & $1,75 \mathrm{~b}$ & $\mathbf{7 3}$ & $12,5 \mathrm{~b}$ \\
$\mathbf{8 0}$ & $74,0 \mathrm{~b}$ & $\mathbf{6 1}$ & $35,0 \mathrm{~b}$ & $\mathbf{6 4}$ & $1,80 \mathrm{~b}$ & $\mathbf{2 3}$ & $12,5 \mathrm{~b}$ \\
$\mathbf{6 4}$ & $74,0 \mathrm{~b}$ & $\mathbf{7 4}$ & $35,5 \mathrm{~b}$ & $\mathbf{2 3}$ & $1,80 \mathrm{~b}$ & $\mathbf{7 7}$ & $12,5 \mathrm{~b}$ \\
$\mathbf{4 2}$ & $76,5 \mathrm{~b}$ & $\mathbf{5 7}$ & $36,0 \mathrm{~b}$ & $\mathbf{5 1}$ & $1,80 \mathrm{~b}$ & $\mathbf{1 6}$ & $12,5 \mathrm{~b}$ \\
$\mathbf{1 2}$ & $77,5 \mathrm{~b}$ & $\mathbf{8}$ & $36,5 \mathrm{~b}$ & $\mathbf{7 8}$ & $1,85 \mathrm{~b}$ & $\mathbf{6 0}$ & $12,5 \mathrm{~b}$ \\
$\mathbf{5 9}$ & $84,5 \mathrm{c}$ & $\mathbf{5 4}$ & $36,5 \mathrm{~b}$ & $\mathbf{5 8}$ & $1,90 \mathrm{~b}$ & $\mathbf{4 1}$ & $13,0 \mathrm{~b}$ \\
$\mathbf{5 8}$ & $86,0 \mathrm{c}$ & $\mathbf{6 2}$ & $37,0 \mathrm{~b}$ & $\mathbf{5 5}$ & $1,95 \mathrm{~b}$ & $\mathbf{8}$ & $13,0 \mathrm{~b}$ \\
$\mathbf{4 3}$ & $86,0 \mathrm{c}$ & $\mathbf{5 6}$ & $38,0 \mathrm{~b}$ & $\mathbf{8 0}$ & $1,95 \mathrm{~b}$ & $\mathbf{6 9}$ & $13,5 \mathrm{c}$ \\
$\mathbf{2 3}$ & $88,0 \mathrm{c}$ & $\mathbf{1 3}$ & $38,5 \mathrm{~b}$ & $\mathbf{5 7}$ & $2,00 \mathrm{~b}$ & $\mathbf{7 2}$ & $14,0 \mathrm{c}$ \\
$\mathbf{1 3}$ & $90,0 \mathrm{c}$ & $\mathbf{6 0}$ & $39,0 \mathrm{~b}$ & $\mathbf{4 2}$ & $2,05 \mathrm{~b}$ & $\mathbf{6 4}$ & $14,0 \mathrm{c}$ \\
$\mathbf{5 7}$ & $91,5 \mathrm{c}$ & $\mathbf{5 5}$ & $40,0 \mathrm{~b}$ & $\mathbf{5 6}$ & $2,10 \mathrm{~b}$ & $\mathbf{7 4}$ & $14,5 \mathrm{c}$ \\
$\mathbf{5 6}$ & $92,0 \mathrm{c}$ & $\mathbf{2 3}$ & $41,0 \mathrm{~b}$ & $\mathbf{4 1}$ & $2,10 \mathrm{~b}$ & $\mathbf{5 8}$ & $14,5 \mathrm{c}$ \\
$\mathbf{5 5}$ & $93,5 \mathrm{c}$ & $\mathbf{5 9}$ & $41,5 \mathrm{~b}$ & $\mathbf{5 4}$ & $2,15 \mathrm{~b}$ & $\mathbf{2}$ & $15,5 \mathrm{c}$ \\
$\mathbf{5 4}$ & $98,0 \mathrm{c}$ & $\mathbf{5 8}$ & $48,0 \mathrm{~b}$ & $\mathbf{4 3}$ & $2,70 \mathrm{~b}$ & $\mathbf{5 9}$ & $17,0 \mathrm{c}$ \\
\hline Média & 62,15 & & 28,88 & & 1,55 & & 10,15 \\
\hline $\mathbf{4}$ & & & &
\end{tabular}

Médias seguidas de letras iguais na vertical não diferem entre si pelo teste de Scott-Knott ao nível de $5 \%$ de significância.

Pelo teste de Scott-Knott, ao nível de 5\% de probabilidade foi possível detectar três grupos de linhagens para a característica altura de planta, dois grupos para a altura de inserção do racemo primário, dois grupos para diâmetro de caule e três grupos para número de nós da haste principal até a primeira inflorescência, no município de Botucatu-SP. 
Tabela 7. Médias gerais para as características altura de plantas (AP), altura de inserção do racemo primário $(\mathrm{AI})$, diâmetro de caule $(\mathrm{DC})$ e número de nós da haste principal até a primeira inflorescência $(\mathrm{NN})$, avaliadas em linhagens de mamona, no município de São Manuel-SP, safrinha de 2008.

\begin{tabular}{|c|c|c|c|c|c|c|c|}
\hline Linhagens & $\begin{array}{l}\mathrm{AP} \\
(\mathbf{c m})\end{array}$ & Linhagens & $\begin{array}{c}\text { AI } \\
(\mathbf{c m})\end{array}$ & Linhagens & $\begin{array}{l}\text { DC } \\
(\mathbf{c m})\end{array}$ & Linhagens & $\mathbf{N N}$ \\
\hline 37 & $75,5 \mathrm{a}$ & 76 & $16,0 \mathrm{a}$ & 14 & $1,75 \mathrm{a}$ & 62 & $8,0 \mathrm{a}$ \\
\hline 4 & $76,5 \mathrm{a}$ & 75 & $16,5 \mathrm{a}$ & 62 & $1,75 \mathrm{a}$ & 61 & $8,0 \mathrm{a}$ \\
\hline 75 & $77,0 \mathrm{a}$ & 79 & $17,5 \mathrm{a}$ & 12 & $1,80 \mathrm{a}$ & 44 & $8,5 \mathrm{a}$ \\
\hline 12 & 84,0 a & 4 & $19,5 \mathrm{a}$ & 44 & $1,90 \mathrm{a}$ & 63 & $8,5 \mathrm{a}$ \\
\hline 76 & 86,0 a & 44 & $21,5 \mathrm{a}$ & 40 & $1,90 \mathrm{a}$ & 10 & $9,0 \mathrm{a}$ \\
\hline 1 & 88,5 a & 37 & $23,0 \mathrm{a}$ & 61 & $1,95 \mathrm{a}$ & 9 & $9,0 \mathrm{a}$ \\
\hline 38 & 89,0 a & 53 & $24,0 \mathrm{a}$ & 17 & $1,95 \mathrm{a}$ & 76 & $9,0 \mathrm{a}$ \\
\hline 40 & $92,0 \mathrm{a}$ & 31 & $24,0 \mathrm{a}$ & 2 & $2,00 \mathrm{a}$ & 79 & $9,0 \mathrm{a}$ \\
\hline 9 & $93,5 \mathrm{a}$ & 30 & $24,0 \mathrm{a}$ & 15 & $2,05 \mathrm{a}$ & 5 & $9,0 \mathrm{a}$ \\
\hline 2 & $95,5 \mathrm{a}$ & 48 & $24,5 \mathrm{a}$ & 18 & $2,10 \mathrm{a}$ & 80 & $9,0 \mathrm{a}$ \\
\hline 6 & 96,0 a & 19 & $25,0 \mathrm{a}$ & 38 & $2,10 \mathrm{a}$ & 57 & $9,0 \mathrm{a}$ \\
\hline 35 & $97,5 \mathrm{a}$ & 5 & $25,0 \mathrm{a}$ & 76 & $2,10 \mathrm{a}$ & 46 & $9,5 \mathrm{a}$ \\
\hline 5 & $99,0 \mathrm{a}$ & 80 & $25,5 \mathrm{a}$ & 36 & $2,15 \mathrm{a}$ & 17 & $9,5 \mathrm{a}$ \\
\hline 62 & $101,0 \mathrm{a}$ & 38 & $26,0 \mathrm{a}$ & 57 & $2,15 \mathrm{a}$ & 21 & $9,5 \mathrm{a}$ \\
\hline 19 & $102,0 \mathrm{a}$ & 51 & $26,0 \mathrm{a}$ & 46 & $2,15 \mathrm{a}$ & 55 & $9,5 \mathrm{a}$ \\
\hline 22 & $102,0 \mathrm{a}$ & 9 & $26,0 \mathrm{a}$ & 5 & $2,15 \mathrm{a}$ & 12 & $9,5 \mathrm{a}$ \\
\hline 36 & $103,0 \mathrm{a}$ & 52 & $26,0 \mathrm{a}$ & 37 & $2,15 \mathrm{a}$ & 53 & $9,5 \mathrm{a}$ \\
\hline 17 & $103,0 \mathrm{a}$ & 12 & $26,5 \mathrm{a}$ & 55 & $2,15 \mathrm{a}$ & 48 & $10,0 \mathrm{~b}$ \\
\hline 61 & $104,0 \mathrm{a}$ & 35 & $27,0 \mathrm{a}$ & 39 & $2,15 \mathrm{a}$ & 29 & $10,0 \mathrm{~b}$ \\
\hline 14 & $105,5 \mathrm{a}$ & 1 & $27,0 \mathrm{a}$ & 23 & $2,20 \mathrm{a}$ & 33 & $10,0 \mathrm{~b}$ \\
\hline 57 & $106,5 \mathrm{a}$ & 29 & $27,5 \mathrm{a}$ & 1 & $2,20 \mathrm{a}$ & 37 & $10,0 \mathrm{~b}$ \\
\hline 44 & $108,0 \mathrm{a}$ & 32 & $27,5 \mathrm{a}$ & 63 & $2,20 \mathrm{a}$ & 56 & $10,0 \mathrm{~b}$ \\
\hline 79 & $108,5 \mathrm{a}$ & 6 & $28,0 \mathrm{a}$ & 19 & $2,20 \mathrm{a}$ & 14 & $10,0 \mathrm{~b}$ \\
\hline 42 & $109,0 \mathrm{a}$ & 36 & $28,0 \mathrm{a}$ & 52 & $2,20 \mathrm{a}$ & 11 & $10,0 \mathrm{~b}$ \\
\hline 39 & $109,0 \mathrm{a}$ & 22 & $28,5 \mathrm{a}$ & 6 & $2,20 \mathrm{a}$ & 52 & $10,0 \mathrm{~b}$ \\
\hline 24 & $112,0 \mathrm{a}$ & 28 & $28,5 \mathrm{a}$ & 42 & $2,25 \mathrm{a}$ & 49 & $10,0 \mathrm{~b}$ \\
\hline 30 & $112,5 \mathrm{a}$ & 47 & $29,0 \mathrm{a}$ & 64 & $2,35 \mathrm{a}$ & 50 & $10,0 \mathrm{~b}$ \\
\hline 74 & $113,0 \mathrm{a}$ & 26 & $29,5 \mathrm{a}$ & 22 & $2,40 \mathrm{a}$ & 32 & $10,5 \mathrm{~b}$ \\
\hline 26 & $114,0 \mathrm{a}$ & 70 & $29,5 \mathrm{a}$ & 79 & $2,40 \mathrm{a}$ & 34 & $10,5 \mathrm{~b}$ \\
\hline 15 & $114,5 \mathrm{a}$ & 21 & $29,5 \mathrm{a}$ & 4 & $2,40 \mathrm{a}$ & 47 & $10,5 \mathrm{~b}$ \\
\hline 29 & $115,5 \mathrm{a}$ & 24 & $30,0 \mathrm{a}$ & 75 & $2,40 \mathrm{a}$ & 31 & $10,5 \mathrm{~b}$ \\
\hline 20 & $116,0 \mathrm{a}$ & 71 & $30,0 \mathrm{a}$ & 16 & $2,45 \mathrm{a}$ & 6 & $10,5 \mathrm{~b}$ \\
\hline 34 & $116,5 \mathrm{a}$ & 33 & $30,0 \mathrm{a}$ & 9 & $2,45 \mathrm{a}$ & 75 & $10,5 \mathrm{~b}$ \\
\hline 18 & $117,5 \mathrm{a}$ & 49 & $30,0 \mathrm{a}$ & 26 & $2,50 \mathrm{a}$ & 22 & $10,5 \mathrm{~b}$ \\
\hline 69 & $118,5 \mathrm{a}$ & 40 & $30,5 \mathrm{a}$ & 8 & $2,50 \mathrm{a}$ & 24 & $10,5 \mathrm{~b}$ \\
\hline 21 & $118,5 \mathrm{a}$ & 2 & $30,5 \mathrm{a}$ & 7 & $2,55 \mathrm{a}$ & 4 & $10,5 \mathrm{~b}$ \\
\hline 7 & $119,5 \mathrm{a}$ & 11 & $30,5 \mathrm{a}$ & 35 & $2,55 \mathrm{a}$ & 26 & $10,5 \mathrm{~b}$ \\
\hline 16 & $120,0 \mathrm{a}$ & 34 & $30,5 \mathrm{a}$ & 60 & $2,60 \mathrm{a}$ & 27 & $\begin{array}{c}10,5 \mathrm{~b} \\
\text { (Continua...) }\end{array}$ \\
\hline
\end{tabular}




\begin{tabular}{|c|c|c|c|c|c|c|c|}
\hline \multicolumn{8}{|c|}{ (...Continuação) } \\
\hline 46 & $121,0 \mathrm{~b}$ & 50 & $31,0 \mathrm{a}$ & 65 & $2,60 \mathrm{a}$ & 28 & $10,5 \mathrm{~b}$ \\
\hline 8 & $121,0 \mathrm{~b}$ & 27 & $32,5 \mathrm{a}$ & 29 & $2,65 \mathrm{~b}$ & 30 & $10,5 \mathrm{~b}$ \\
\hline 55 & $123,0 \mathrm{~b}$ & 3 & $32,5 \mathrm{a}$ & 34 & $2,65 \mathrm{~b}$ & 18 & $10,5 \mathrm{~b}$ \\
\hline 3 & $123,5 \mathrm{~b}$ & 42 & $33,0 \mathrm{a}$ & 53 & $2,65 \mathrm{~b}$ & 13 & $10,5 \mathrm{~b}$ \\
\hline 54 & $123,5 \mathrm{~b}$ & 20 & $33,5 \mathrm{a}$ & 24 & $2,70 \mathrm{~b}$ & 66 & $11,0 \mathrm{~b}$ \\
\hline 47 & $125,5 \mathrm{~b}$ & 10 & $33,5 \mathrm{a}$ & 33 & $2,70 \mathrm{~b}$ & 25 & $11,0 \mathrm{~b}$ \\
\hline 51 & $125,5 \mathrm{~b}$ & 39 & $34,0 \mathrm{a}$ & 68 & $2,70 \mathrm{~b}$ & 38 & $11,0 \mathrm{~b}$ \\
\hline 25 & $126,5 \mathrm{~b}$ & 25 & $34,0 \mathrm{a}$ & 47 & $2,70 \mathrm{~b}$ & 39 & $11,0 \mathrm{~b}$ \\
\hline 53 & $127,5 \mathrm{~b}$ & 7 & $34,5 \mathrm{a}$ & 28 & $2,75 \mathrm{~b}$ & 35 & $11,0 \mathrm{~b}$ \\
\hline 68 & $128,0 \mathrm{~b}$ & 46 & $35,0 \mathrm{a}$ & 10 & $2,80 \mathrm{~b}$ & 36 & $11,0 \mathrm{~b}$ \\
\hline 64 & $128,5 \mathrm{~b}$ & 78 & $35,0 \mathrm{a}$ & 77 & $2,80 \mathrm{~b}$ & 3 & $11,0 \mathrm{~b}$ \\
\hline 65 & $129,5 \mathrm{~b}$ & 8 & $35,0 \mathrm{a}$ & 69 & $2,80 \mathrm{~b}$ & 65 & $11,0 \mathrm{~b}$ \\
\hline 11 & $130,0 \mathrm{~b}$ & 14 & $35,5 \mathrm{a}$ & 30 & $2,80 \mathrm{~b}$ & 1 & $11,0 \mathrm{~b}$ \\
\hline 66 & $130,0 \mathrm{~b}$ & 17 & $36,0 \mathrm{a}$ & 3 & $2,85 \mathrm{~b}$ & 8 & $11,0 \mathrm{~b}$ \\
\hline 27 & $130,0 \mathrm{~b}$ & 43 & $36,0 \mathrm{a}$ & 58 & $2,85 \mathrm{~b}$ & 2 & $11,5 \mathrm{c}$ \\
\hline 52 & $130,0 \mathrm{~b}$ & 61 & $37,0 \mathrm{~b}$ & 20 & $2,85 \mathrm{~b}$ & 58 & $11,5 \mathrm{c}$ \\
\hline 70 & $130,5 \mathrm{~b}$ & 62 & $37,0 \mathrm{~b}$ & 27 & $2,90 \mathrm{~b}$ & 23 & $11,5 \mathrm{c}$ \\
\hline 33 & $130,5 \mathrm{~b}$ & 18 & $37,5 \mathrm{~b}$ & 11 & $2,90 \mathrm{~b}$ & 20 & $11,5 \mathrm{c}$ \\
\hline 48 & $131,0 \mathrm{~b}$ & 15 & $38,0 \mathrm{~b}$ & 21 & $2,90 \mathrm{~b}$ & 70 & $12,0 \mathrm{c}$ \\
\hline 28 & $132,0 \mathrm{~b}$ & 66 & $39,0 \mathrm{~b}$ & 41 & $2,90 \mathrm{~b}$ & 67 & $12,0 \mathrm{c}$ \\
\hline 80 & $132,0 \mathrm{~b}$ & 16 & $39,0 \mathrm{~b}$ & 51 & $3,00 \mathrm{~b}$ & 68 & $12,0 \mathrm{c}$ \\
\hline 10 & $132,5 \mathrm{~b}$ & 69 & $39,5 \mathrm{~b}$ & 32 & $3,00 \mathrm{~b}$ & 42 & $12,0 \mathrm{c}$ \\
\hline 50 & $133,0 \mathrm{~b}$ & 41 & $40,0 \mathrm{~b}$ & 74 & $3,00 \mathrm{~b}$ & 43 & $12,0 \mathrm{c}$ \\
\hline 78 & $135,5 \mathrm{~b}$ & 67 & $40,5 \mathrm{~b}$ & 48 & $3,05 \mathrm{~b}$ & 40 & $12,0 \mathrm{c}$ \\
\hline 67 & $136,0 \mathrm{~b}$ & 72 & $41,5 \mathrm{~b}$ & 67 & $3,05 \mathrm{~b}$ & 16 & $12,0 \mathrm{c}$ \\
\hline 63 & $136,5 \mathrm{~b}$ & 57 & $42,0 \mathrm{~b}$ & 25 & $3,05 \mathrm{~b}$ & 19 & $12,0 \mathrm{c}$ \\
\hline 31 & $139,5 \mathrm{~b}$ & 68 & $43,0 \mathrm{~b}$ & 80 & $3,05 \mathrm{~b}$ & 54 & $12,0 \mathrm{c}$ \\
\hline 59 & $143,5 \mathrm{~b}$ & 63 & $43,0 \mathrm{~b}$ & 54 & $3,10 \mathrm{~b}$ & 60 & $12,5 \mathrm{c}$ \\
\hline 60 & $147,0 \mathrm{~b}$ & 54 & $43,5 \mathrm{~b}$ & 66 & $3,10 \mathrm{~b}$ & 7 & $12,5 \mathrm{c}$ \\
\hline 56 & $150,0 \mathrm{~b}$ & 64 & $43,5 \mathrm{~b}$ & 59 & $3,15 \mathrm{~b}$ & 15 & $12,5 \mathrm{c}$ \\
\hline 71 & $150,0 \mathrm{~b}$ & 65 & $43,5 \mathrm{~b}$ & 31 & $3,15 \mathrm{~b}$ & 77 & $12,5 \mathrm{c}$ \\
\hline 41 & $150,0 \mathrm{~b}$ & 55 & $44,0 \mathrm{~b}$ & 56 & $3,15 \mathrm{~b}$ & 72 & $12,5 \mathrm{c}$ \\
\hline 43 & $150,5 \mathrm{~b}$ & 74 & $44,5 \mathrm{~b}$ & 71 & $3,20 \mathrm{~b}$ & 51 & $12,5 \mathrm{c}$ \\
\hline 77 & $154,5 \mathrm{~b}$ & 13 & $49,5 \mathrm{c}$ & 72 & $3,30 \mathrm{~b}$ & 64 & $13,0 \mathrm{c}$ \\
\hline 49 & $155,0 \mathrm{~b}$ & 23 & $54,0 \mathrm{c}$ & 49 & $3,50 \mathrm{~b}$ & 78 & $13,5 \mathrm{c}$ \\
\hline 13 & $157,0 \mathrm{~b}$ & 56 & $55,0 \mathrm{c}$ & 78 & $3,55 \mathrm{~b}$ & 59 & $13,5 \mathrm{c}$ \\
\hline 73 & $161,0 \mathrm{~b}$ & 60 & $55,0 \mathrm{c}$ & 23 & $3,60 \mathrm{~b}$ & 41 & $14,0 \mathrm{c}$ \\
\hline 72 & $161,5 \mathrm{~b}$ & 59 & $57,0 \mathrm{c}$ & 73 & $3,70 \mathrm{~b}$ & 69 & $14,5 \mathrm{c}$ \\
\hline 58 & $164,5 \mathrm{~b}$ & 73 & $59,0 \mathrm{c}$ & 43 & $3,75 \mathrm{~b}$ & 74 & $17,0 \mathrm{~d}$ \\
\hline 23 & $182,5 \mathrm{~b}$ & 58 & $67,0 \mathrm{c}$ & 50 & $3,90 \mathrm{~b}$ & 73 & $18,0 \mathrm{~d}$ \\
\hline Média & 120,55 & & 33,9 & & 2,60 & & 10,95 \\
\hline
\end{tabular}

Médias seguidas de letras iguais na vertical não diferem entre si pelo teste de Scott-Knott ao nível de $5 \%$ de significância. 
Nos resultados encontrados para o município de São Manuel-SP, foi possível detectar dois grupos de linhagens para a característica altura de planta, três grupos para a altura de inserção do racemo primário, dois grupos para diâmetro de caule e quatro grupos para número de nós da haste principal até a primeira inflorescência.

Com relação aos valores médios de altura de plantas (m), altura de inserção do racemo primário e número de nós da haste principal até a primeira inflorescência, para as 80 linhagens avaliadas nos municípios de Botucatu-SP e São Manuel-SP, observou-se grande amplitude de variação para essas características.

As médias gerais de altura de planta foram 62,15 e 120,55 cm, para os municípios de Botucatu-SP e São Manuel-SP, respectivamente. De acordo com a escala adaptada de Veiga et al. (1989), as linhagens avaliadas em Botucatu-SP são consideradas plantas anãs, com alturas menores que $90 \mathrm{~cm}$. Em São Manuel-SP, as linhagens foram consideradas em termos médios como muito baixas $(91 \mathrm{a} 150 \mathrm{~cm})$.

$\mathrm{O}$ porte baixo e anão apresentado pelas linhagens de mamona mostram-se interessante para a produção de híbridos para a colheita mecanizada, sobretudo para híbridos para as condições de safra, onde a tendência das plantas é apresentar um maior crescimento. Do cruzamento de tais linhagens anãs, podem resultar híbridos promissores para a colheita mecanizada.

Os valores médios de altura de inserção do racemo também mostraram-se aptos à colheita mecanizada, com médias de $28,88 \mathrm{~cm}$ e 36,9 cm, em BotucatuSP e São Manuel-SP, respectivamente.

As médias gerais da característica diâmetro de caule de 1,55 e 2,60 em Botucatu-SP e São Manuel, respectivamente, são considerados como finos (NÓBREGA et al., 2001). Essa característica também é importante na obtenção de genótipos de mamona para cultivo mecanizado.

Com relação ao número de nós da haste principal até a primeira inflorescência, foram observados os valores de 10,15 e 10,95 nós para os municípios de Botucatu e São Manuel, considerado como baixo segundo a escala descrita por Nóbrega et al. (2001), pois as médias não foram superiores a 16 nós. O número de nós da haste principal até a primeira inflorescência é uma característica relacionada com a precocidade da planta, sendo 
considerada mais precoce a planta que produz o primeiro racemo com menor número de nós. Shifriss (1960), afirma que a característica é normalmente constante sob uma série de condições ambientais, contudo, pode variar amplamente dependendo do genótipo, com valores entre 6 a mais de 90 nós. Para os resultados do município de Botucatu - SP e São Manuel SP, a média da maior parte das linhagens apresentou como número de nós baixo, indicando que esses materiais são precoces, fator importante para um cultivo mais rentável da mamoneira.

Na Tabela 8 estão apresentados os quadrados médios, respectivas significâncias pelo teste $\mathrm{F}$ e coeficientes de variação experimental da análise conjunta, das linhagens de mamona para as características altura de plantas $(\mathrm{cm})$, altura de inserção do racemo primário $(\mathrm{cm})$, diâmetro de caule e número de nós na haste até a inflorescência, em Botucatu - SP e São Manuel - SP, na safrinha 2008.

Tabela 8. Quadrados médios, respectivas significâncias pelo teste $\mathrm{F}$ e coeficientes de variação experimental da análise conjunta, das linhagens de mamona para as características altura de plantas $(\mathrm{cm})$, altura de inserção do racemo primário $(\mathrm{cm})$, diâmetro de caule e número de nós na haste até a inflorescência, em Botucatu - SP e São Manuel - SP, na safrinha 2008.

\begin{tabular}{cccccc}
\hline F.V. & G.L. & AP $(\mathrm{cm})$ & AI $(\mathrm{cm})$ & DC $(\mathrm{cm})$ & NN \\
\hline Blocos & 1 & 4627,04 & 3,17 & 3,42 & 4,51 \\
Locais(Lo) & 1 & $262539,28^{* *}$ & $1945,17 * *$ & $85,36 * *$ & $43,53 * *$ \\
Linhagem(Li) & 78 & $920,44^{* *}$ & $223,77^{* *}$ & $0,40 * *$ & $13,47 * *$ \\
Li x Lo & 78 & $395,83^{\text {ns }}$ & $41,52^{\text {ns }}$ & $0,22 * *$ & $2,34 * *$ \\
Erro & 234 & 302,40 & 30,83 & 0,13 & 1,32 \\
\hline Média & & 91,12 & 31,31 & 2,07 & 10,50 \\
CV $(\%)$ & & 19,08 & 17,73 & 17,60 & 10,97 \\
\hline
\end{tabular}

** significativo e ${ }^{\text {ns }}$ não significativo, a $5 \%$ de probabilidade pelo teste $\mathrm{F}$.

Os quadrados médios da análise conjunta para os municípios de Botucatu- SP e São Manuel-SP, foram significativos ao nível de 5\% de probabilidade, para locais, linhagens e para a interação de linhagens e locais, nas características diâmetro de caule e número de nós da haste principal até a primeira inflorescência. As linhagens apresentaram comportamento diferencial em relação aos locais para tais características, não podendo ser comparadas em termos médios. Entretanto, para as características altura de planta e altura de 
inserção do racemo primário, o quadrado da interação linhagem e local não foi significativo, não apresentando as linhagens comportamento diferencial nos municípios de Botucatu-SP e São Manuel, podendo ser comparadas em termos médios. Contudo, os quadrados médios para locais e linhagens foram significativos para estas características (Tabela 8).

Na Tabela 9, são apresentados os valores médios das linhagens de mamona para as características altura de planta e altura de inserção do racemo primário, nos dois municípios, na safrinha de 2008.

Tabela 9. Médias das linhagens de mamona para as características altura de plantas (AP) e altura de inserção do racemo primário (AI) nos municípios de Botucatu - SP e São Manuel, na safrinha de 2008.

\begin{tabular}{|c|c|c|c|}
\hline & Dois locais & & Dois locais \\
\hline Linhagens & $\mathbf{A P}(\mathbf{c m})$ & Linhagens & AI (cm) \\
\hline 37 & $55,48 \mathrm{a}$ & 76 & $15,58 \mathrm{a}$ \\
\hline 75 & $62,38 \mathrm{a}$ & 75 & $17,45 \mathrm{a}$ \\
\hline 76 & $64,03 \mathrm{a}$ & 79 & $20,60 \mathrm{a}$ \\
\hline 1 & $69,70 \mathrm{a}$ & 44 & $22,13 \mathrm{a}$ \\
\hline 40 & $69,73 \mathrm{a}$ & 37 & $22,33 \mathrm{a}$ \\
\hline 4 & $71,25 \mathrm{a}$ & 38 & $22,40 \mathrm{a}$ \\
\hline 68 & 71,77 a & 50 & $22,50 \mathrm{a}$ \\
\hline 38 & $71,97 \mathrm{a}$ & 5 & $23,00 \mathrm{a}$ \\
\hline 66 & $73,60 \mathrm{a}$ & 49 & $23,10 \mathrm{a}$ \\
\hline 5 & $73,70 \mathrm{a}$ & 80 & $23,55 \mathrm{a}$ \\
\hline 6 & $74,65 \mathrm{a}$ & 48 & $23,65 \mathrm{a}$ \\
\hline 36 & $75,33 \mathrm{a}$ & 4 & $23,78 \mathrm{a}$ \\
\hline 35 & $75,73 \mathrm{a}$ & 1 & $23,95 \mathrm{a}$ \\
\hline 9 & $77,00 \mathrm{a}$ & 53 & $24,43 \mathrm{a}$ \\
\hline 34 & $79,23 \mathrm{a}$ & 31 & $24,68 \mathrm{a}$ \\
\hline 22 & $79,25 \mathrm{a}$ & 52 & $24,73 \mathrm{a}$ \\
\hline 44 & $79,93 \mathrm{a}$ & 9 & $25,50 \mathrm{a}$ \\
\hline 39 & $80,68 \mathrm{a}$ & 70 & $25,58 \mathrm{a}$ \\
\hline 61 & $80,70 \mathrm{a}$ & 19 & $26,08 \mathrm{a}$ \\
\hline 19 & $80,85 \mathrm{a}$ & 51 & $26,10 \mathrm{a}$ \\
\hline 12 & $80,88 \mathrm{a}$ & 36 & $26,33 \mathrm{a}$ \\
\hline 26 & $81,58 \mathrm{a}$ & 29 & $27,00 \mathrm{~b}$ \\
\hline 62 & $81,90 \mathrm{a}$ & 71 & $27,03 \mathrm{~b}$ \\
\hline 2 & $82,00 \mathrm{a}$ & 6 & $27,13 b$ \\
\hline 17 & $82,48 \mathrm{a}$ & 3 & $27,58 \mathrm{~b}$ \\
\hline 24 & $82,90 \mathrm{a}$ & 21 & $27,60 \mathrm{~b}$ \\
\hline 16 & $83,45 \mathrm{a}$ & 35 & $\begin{array}{r}27,83 \mathrm{~b} \\
\text { (Continua }\end{array}$ \\
\hline
\end{tabular}




\section{(...Continuação)}

74

69

70

50

30

29

32

25

46

79

71

3

33

20

49

21

7

15

51

48

14

65

42

18

27

8

31

47

53

28

57

11

10

52

63

64

78

80

55

60

73

41
83,98 a $\quad 34$

84,85 a $\quad 47$

85,35 a $\quad 30$

86,73 a

86,80 a $\quad 26$

87,00 a $\quad 32$

87,38 a $\quad 22$

87,78 a $\quad 33$

87,95 a

88,13 a

88,17 a

88,40 a

88,80 a

90,05 a

90,77 a

91,25 a

91,35 a

91,43 a

$92,20 \mathrm{a}$

92,28 a

92,33 a

92,50 a

92,88 a

94,10 a

94,30 a

95,15 a

95,33 a

95,45 a

$97,10 \mathrm{~b}$

$98,45 \mathrm{~b}$

$98,80 \mathrm{~b}$

99,03 b

99,28 b

$100,35 \mathrm{~b}$

$100,85 \mathrm{~b}$

$101,00 \mathrm{~b}$

$102,68 \mathrm{~b}$

$103,00 \mathrm{~b}$

$108,18 \mathrm{~b}$

$108,73 \mathrm{~b}$

$109,38 \mathrm{~b}$

$110,50 \mathrm{~b}$
$27,98 \mathrm{~b}$

$28,20 \mathrm{~b}$

$28,40 \mathrm{~b}$

$28,45 \mathrm{~b}$

$28,50 \mathrm{~b}$

$28,58 \mathrm{~b}$

$29,05 \mathrm{~b}$

$29,18 \mathrm{~b}$

$29,60 \mathrm{~b}$

$30,10 \mathrm{~b}$

$30,15 \mathrm{~b}$

$30,25 \mathrm{~b}$

$30,25 \mathrm{~b}$

$30,35 \mathrm{~b}$

$30,63 \mathrm{~b}$

$30,78 \mathrm{~b}$

$30,93 \mathrm{~b}$

$30,98 \mathrm{~b}$

$31,13 \mathrm{~b}$

$31,68 \mathrm{~b}$

$31,78 \mathrm{~b}$

$31,80 \mathrm{~b}$

$31,98 \mathrm{~b}$

$32,15 \mathrm{~b}$

$32,20 \mathrm{~b}$

33,03 b

$33,20 \mathrm{~b}$

$33,43 \mathrm{~b}$

$33,48 \mathrm{~b}$

$33,85 \mathrm{~b}$

$33,90 \mathrm{~b}$

$34,25 \mathrm{~b}$

$35,10 \mathrm{c}$

$35,65 \mathrm{c}$

$35,70 \mathrm{c}$

$35,90 \mathrm{c}$

$36,95 \mathrm{c}$

$37,23 \mathrm{c}$

$37,50 \mathrm{c}$

$37,93 \mathrm{c}$

$38,45 \mathrm{c}$

$39,10 \mathrm{c}$

(Continua...) 


\begin{tabular}{cccc}
\hline (...Continuação) & & & \\
$\mathbf{5 4}$ & $110,60 \mathrm{~b}$ & $\mathbf{7 4}$ & $39,98 \mathrm{c}$ \\
$\mathbf{7 2}$ & $111,20 \mathrm{~b}$ & $\mathbf{5 4}$ & $40,15 \mathrm{c}$ \\
$\mathbf{7 7}$ & $113,15 \mathrm{~b}$ & $\mathbf{5 5}$ & $42,13 \mathrm{c}$ \\
$\mathbf{5 9}$ & $113,98 \mathrm{~b}$ & $\mathbf{1 3}$ & $44,10 \mathrm{~d}$ \\
$\mathbf{6 7}$ & $114,87 \mathrm{~b}$ & $\mathbf{5 6}$ & $46,08 \mathrm{~d}$ \\
$\mathbf{4 3}$ & $118,18 \mathrm{~b}$ & $\mathbf{7 3}$ & $46,15 \mathrm{~d}$ \\
$\mathbf{5 6}$ & $120,90 \mathrm{~b}$ & $\mathbf{6 0}$ & $46,65 \mathrm{~d}$ \\
$\mathbf{1 3}$ & $123,45 \mathrm{~b}$ & $\mathbf{2 3}$ & $47,33 \mathrm{~d}$ \\
$\mathbf{5 8}$ & $125,25 \mathrm{~b}$ & $\mathbf{5 9}$ & $48,85 \mathrm{~d}$ \\
$\mathbf{2 3}$ & $135,43 \mathrm{~b}$ & $\mathbf{5 8}$ & $57,38 \mathrm{e}$ \\
\hline Média & 91,05 & Média & 31,31 \\
\hline
\end{tabular}

Médias seguidas de letras iguais na vertical não diferem entre si pelo teste de Scott-Knott ao nível de $5 \%$ de significância.

Pelo teste de Scott-Knott, ao nível de 5\% de probabilidade foi possível detectar dois grupos de linhagens para a característica altura de plantas e cinco grupo de linhagens para altura de inserção do racemo primário, evidenciando que a última característica foi mais variável nas linhagens avaliadas.

Foi verificada grande variabilidade entre as linhagens para as características altura de plantas, altura de inserção do racemo primário, diâmetro de caule e número de nós até a inflorescência primária. Todas as linhagens apresentaram-se promissoras para a produção de híbridos para a colheita mecanizada.

A característica de racemo pistilado nas linhagens de mamona não foi relacionada com as outras características avaliadas nas plantas de mamona, o que seria de grande interesse para o melhoramento genético, para ser usada como marcador morfológico. Myczkowski (2006) observou na seleção para aumento da porcentagem de flores femininas em mamoneira, que as plantas que foram selecionadas com maior porcentagem de flores femininas mostraram-se ligeiramente mais altas que as testemunhas.

Contudo, o que se observa é que as linhagens que passaram por mais ciclos de seleção e autofecundação, como as linhagens com a designação MRZ, apresentaram uma maior freqüência de plantas femininas. Esses dados concordam com os resultados de Myczkowski (2006), que também observou aumento da freqüência de flores femininas nas 
progênies de plantas com reversão sexual que tiveram os racemos secundários e/ou terciários autofecundados.

A expressão sexual em mamona é de natureza complexa e até agora pouco foi elucidado, havendo ainda muitas contradições encontradas na literatura e em resultados de experimentos. A instabilidade sexual é um fenômeno prevalente em mamona e mais estudos são necessários, para se entender o sistema ou os sistemas que governam a herança do sexo na planta.

Os programas de melhoramento genético da mamoneira visam à obtenção de cultivares mais produtivas, de porte médio para facilitar a colheita, precoces e com elevados teores de óleo. Dentre todas as características citadas, sem dúvida a produtividade é a de maior relevância. O conhecimento do caráter sexual implicará em grandes avanços nos programas de melhoramento genético da mamoneira, tanto na obtenção de plantas mais produtivas, como na facilidade de obtenção de híbridos. 


\section{CONCLUSÕES}

As condições ambientais do município de Botucatu-SP, no ano de 2008, em condições de safrinha, foram mais favoráveis à expressão da característica pistilada nas linhagens de mamona, apresentando uma maior freqüência de plantas femininas estáveis, em comparação com as condições ambientais do município de São Manuel-SP. Em algumas linhagens, a seleção para a característica pistilada não foi eficiente, indicando que mais ciclos de seleção são necessários. O ambiente influenciou a expressão sexual em mamoneira. 


\section{REFERÊNCIAS BIBLIOGRÁFICAS}

AMARAL, J. G. C. Variabilidade genética para características agronômicas entre progênies autofecundadas de mamona (Ricinus communis L.) cv AL Guarany 2002. 2003. 59 f. Tese (Doutorado em Agronomia) - Universidade Estadual Paulista, Faculdade de Ciências Agronômicas, Botucatu.

AZEVEDO, D. M. P. de; BELTRÃO, N. E. de M.; SANTOS, J. W. dos; VIEIRA, D. J.; LIMA, E. F.; BATISTA F. A. S.; PEREIRA, J. R. Efeito de população de plantas no rendimento do consórcio de mamona com culturas alimentares. Revista brasileira de oleaginosas e fibrosas, Campina Grande: Embrapa Algodão, v. 2, n. 3, p. 193-202. set-dez. de 1998.

AZEVEDO, D. M. P. de; BELTRÃO, N. E. de M. (Ed.). O agronegócio da mamona no Brasil. 2 ed. rev. amp. Campina Grande: Embrapa Algodão; Brasília, DF: Embrapa Informação Tecnológica, 2007. 506 p.

BELTRÃO, N. E. de M.; SILVA, L. C. Os múltiplos usos do óleo da mamoneira (Ricuns communis L.) e a importância do seu cultivo no Brasil. Fibras e Óleos, Campina Grande, n. 31, 1999. 
BELTRÃO, N. E. de M.; SILVA, L. C.; VASCONCELOS, O. L.; AZEVEDO, D. M. P.; VIEIRA, D. J. Fitologia. In: AZEVEDO, D. M. P. de; LIMA, E. F. (Eds.). O agronegócio da mamona no Brasil. Brasília: Embrapa informação tecnológica, 2001. cap. 2, p. 37-62.

BELTRÃO, N. E. de M.; SOUZA, J. Z.; SANTOS, J. W.; JERÔNIMO, J. F.; COSTA, F. X.; LUCENA, A. M. A. de; QUEIROZ, U. C. de. Fisiologia da mamoneira, cultivar BRS 149 Nordestina na fase inicial de crescimento, submetida a estresse hídrico. Revista brasileira de oleaginosas e fibrosas, Campina Grande: Embrapa Algodão, v. 7, n. 1, p. 659-664. jan-abr., 2003.

BELTRÃO, N. E. de M; CARDOSO, G. D. Informações sobre o sistema de produção utilizados na ricinocultura na região Nordeste, em especial o semiárido e outros aspectos ligados a sua cadeia. Campina Grande: Embrapa Algodão, 2006, 6 p. (Comunicado Técnico, 213).

BERTOZZO, F. Avaliação da seleção para aumento da porcentagem de flores pistiladas em mamona (Ricinus communis L.). 2009. 36 f. Dissertação (mestrado em Agronomia Agricultura), Faculdade de Ciências Agronômicas, Universidade Estadual Paulista, Botucatu.

BRINHOLI, O. Cultura da mamoneira (Ricinus communis L.). 1995. 105 f. Tese (doutorado em Agronomia - Agricultura), Faculdade de Ciências Agronômicas, Universidade Estadual Paulista, Botucatu.

CARVALHO, L. O. Mamona (Ricinus Communis L.), In: SÃO PAULO (Estado) Secretaria de Agricultura e Abastecimento Coordenadoria de Assistência Técnica Integral. Manual técnico das culturas. 2 ed. Campinas, 1997. cap. 11, p. 349-368.

CLAASSEN, C. E.; HOFFMAN, A. The inheritance of the pistillate character in castors and its possible utilization in the production of commercial hybrid seed. Agronomy Journal, Nebraska, n. 42, p. 79-82, jul. 1949. 
DUKE, J. A. Ricinus communis L. Handbook of Energy Crops. Purdue, 1983. Disponível em: < http://www.hort.purdue.edu/newcrop/duke_energy/Ricinus_communis.html >. Acesso em: 20 de novembro. 2009.

EMBRAPA. Centro Nacional de Pesquisa de Algodão (Campina Grande, Paraíba). Nova Cultivar de mamona, BRS 149 (Nordestina). Campina Grande, EMBRAPA/CNPA/EBDA, 1998. (Folder).

FERREIRA, D.F. Sisvar versão 4.2. DEX/UFLA, 2003.

FILKAUSKAS, J. Mercados para a mamona e importância da qualidade da matéria-prima. In: Simpósio do Agronegócio de Plantas oleaginosas, 1., 2001, Piracicaba. Trabalhos apresentados... Piracicaba: Ceralit, 2001. 11 p.

FREIRE, R. M. M. Ricinoquímica. In: AZEVEDO, D. M. P. de; LIMA, E. F. (Eds.). O agronegócio da mamona no Brasil. Brasília: Embrapa informação tecnológica, 2001. cap. 13, p. 295-336.

GEORGE, J.R.; SHIFRISS, O. Interspersed sexuality in Ricinus. Genetics, n.57, p.347-356, 1967.

GIBELLI, F. Projeto poliuretano de óleo de mamona e seus subprodutos. In: CÂMARA, G.M.S., CHIAVEGATO, E.J. (Coord.). O agronegócio das plantas oleaginosas. Piracicaba: Escola Superior de Agricultura "Luis de Queiroz" / Departamento Produção Vegetal, 2001. cap.10, p. 181-184.

GONÇALVES, N. P.; KAKIDA, J.; LELES, W. D. Cultivares de mamona. Informe Agropecuário, Belo Horizonte, v. 7, n. 82, p. 31-33, out. 1981. 
GURGEL, J. T. A. Estudos sobre a mamoneira (Ricinus communis L). Piracicaba, 1945. 70p. Tese para concurso para Docente Livre da Cadeira de Citologia e Genética Geral Escola Superior de Agricultura “Luiz de Queiroz”, USP.

HEMERLY, F. X. Mamona: Comportamento e tendências no Brasil. Brasília: Embrapa Departamento de Informação e Documentação. 1981. 63p.

IBGE-INSTITUTO BRASILEIRO DE GEOGRAFIA E ESTATÍSTICA. Produção agrícola municipal culturas temporárias e permanentes Disponível em:<http://www.ibge.gov.br/home/estatistica/indicadores/agropecuaria/lspa/lspa_200906_6.sh tm>. Acesso em: 20 junho 2009.

KHRYANIN, V. N. Role of phytohormones in sex differentiation in plants. Russian Journal of Plant Physiology, v. 49, n. 4, 2002, p. 545-551.

KRUG, C. A.; MENDES, P. T. Melhoramento da mamoneira (Ricinus communis L) I- plano geral dos trabalhos em execução nas seções de genética e plantas oleaginosas do Instituto Agronômico do Estado de São Paulo. Bragantia, v. 2, p.129-154, 1942.

KUMAR, N.P.; RAO, P. G. Activity of auxinlike substances in relation to feminization of castor bean (Ricinus communis L.) influenced by kinetin and morphactin. Turrialba, v. 31 (33), p. 201-208, 1981.

LAURETI, D.; BRIGHAM, R. D. Genetica e miglioramento del ricino. In: Ministero dell'Agricoltura e Foreste, ed. Il Ricino- obiettivi, Strategie e ricerca. 1987, p. 11-22.

LAVANYA, C. Sensitivity of sex expression and sex variation in castor (Ricinus communis L.) to environmental changes. Indian Journal of Genetics and Plant Breeding, v. 62, n. 3, p. 232-237, 2002. 
LORENZI, H. (Ed.). Plantas daninhas do Brasil: aquáticas, terrestres e tóxicas. 3. ed. Nova Odessa-SP: Plantarum, 2000. 608p.

MYCZKOWSKI, M. L. Seleção para aumento da porcentagem de flores femininas na população FCA-UNESP-PB de mamona (Ricinus communis L.). 2006. 33 f. Tese (doutorado em Agronomia - Agricultura), Faculdade de Ciências Agronômicas, Universidade Estadual Paulista, Botucatu.

MOSHKIN, V. A. Ecology. In: MOSHKIN, V. A. (Ed.). Castor. New Delhi: Amerind, 1986. p. 54-64.

NÓBREGA, M. B. M.; ANDRADE, F. P.; SANTOS, J. W.; LEITE, E. J. Germoplasma. In: AZEVEDO, D. M. P. de; LIMA, E. F. (Eds.) O agronegócio da mamona no Brasil. Brasília: Embrapa Informação Tecnológica, 2001. p. 257-281.

OLSNES, S. The history of ricin, abrin and related toxins. Toxicon, v. 44, p. 361-370, 2004.

OPLINGER, E. S.; OELKE, E. A; KAMINSKI, A R.; COMBS, S. M.; DOLI, J. D; SCHULER, R. T. Ricinus communis L. Field crops manual, Purdue, 1997. Disponível em: <http://www.hort.purdue.edu/newcrop/afcm/castor.html>. Acesso em: 20 de nov. 2009.

PATEL, I. D.; DANGARIA, C. J.; PATEL, V. J. Induction of male sex in pistillate lines of castor. Indian Journal of Agricultural Sciences, Gujarat, v. 56, n. 8, p. 556-558, aug. 1986.

POPOVA, G. M.; MOSHKIN, V. A. Botanical classification. In: MOSHKIN, V. A. (Eds)

Castor. New Delhi: Amerinda. 1986. p. 11-27.

RODRIGUES, R. F. O.; OLIVEIRA, F.; FONSECA, A. M. As folhas de Palma Christi Ricinus communis L. Euphorbiaceae Jussieu. Revisão de conhecimentos, Revista Lecta, Bragança Paulista, v. 20, n. 2, p. 183-194, jul./dez. 2002. 
SAVY FILHO, A. Mamona, In: RAIJ B. van (Ed) Recomendações de adubação e calagem para o Estado de São Paulo, Campinas: Instituto Agronômico/ Fundação IAC, 1997. 285 p.

SAVY FILHO, A. Melhoramento de mamona. In: BORÉM, A. (Ed.). Melhoramento de espécies cultivadas. Viçosa: Editora da Universidade Federal de Viçosa, 1999a. p. 398-404.

SAVY FILHO, A. Hibridação em mamoma. In: BORÉM, A. (Ed.). Hibridação Artificial de Plantas. Viçosa: UFV, 1999b. 546p.

SAVY FILHO, A. Mamona Tecnologia Agrícola. Campinas: EMOPI, 2005. 105 p.

SANCHES, V. Fraturas: um problema do passado. Jornal da Cidade, Bauru, 6 jul. 2003. JC Saúde. p. 3.

SÃO PAULO (Estado). Secretaria de Agricultura e Abastecimento. Coordenadoria de Assistência Técnica Integral. Oleaginosas no Estado de São Paulo: análise e diagnóstico: subsídios da Comissão Técnica de Oleaginosas. Campinas: CATI, 1998. 39 p. (Documento técnico, 107).

SHIFRISS, O. Sex instability in Ricinus. The Weizmann Institute of Science, Rehovot, Israel, v. 28, p. 265-280, sept. 1956.

SHIFRISS, O. Conventional and unconventional systems controlling sex varioyions in ricinus. The Weizmann Institute of Science, p.361-388, 1960.

SOLANKY, S. S.; JOSHI, P. Inheritance of sex in castor (Ricinus communis L.). Indian Journal Genetic.n. 60 (1), p. 97-104, 2000.

TÁVORA, F. J. A. A cultura da mamona. Fortaleza: EPACE, 1982. 111p. 
VEIGA, R. F. A.; SAVY FILHO, A.; BANZATTO, N. V. Descritores mínimos para caracterização e avaliação de mamoneira (Ricinus communis L.) aplicados no Instituto Agronômico. Campinas: Instituto Agronômico, IAC, 1989, 16p. (Boletim técnico, 125).

ZANOTTO, M. D., AMARAL, J. G. C.; POLETINE, J.P. Seleção recorrente com utilização de progênies autofecundadas para diminuição da altura da planta de mamona (Ricinus communis L.) população Guarani comum. In: CONGRESSO BRASILEIRO DE MAMONA, 1., Anais... 2004, Campina Grande. Energia e sustentabilidade. Disponível em: <http://www.cnpa.embrapa.br/produtos/mamona/publicacoes/trabalhos_cbm1/066.PDF>. Acesso em: 22 nov. 2009.

ZIMMERMAN, L. H.; SMITH, J. D. Production of F1 seed in castor-beans by use of sex genes sensitive to environment. Crop Science, n. 6, p. 406-409, 1966.

WEISS, E. A. Castor, Sesame and Safflower. London: Leonard Hill Books, 1971.

WEISS, E. A. Oilseed crops. London: Longman, 1983. 660p. 